Article

\title{
Digital Construction Technology and Job-Site Equipment Demonstration: Modelling Relationship Strategies for Technology Adoption
}

\author{
Samad M. E. Sepasgozar ${ }^{1, *}$ and Steven Davis ${ }^{2}$ \\ 1 Faculty of Built Environment, University of New South Wales, Sydney 2052, Australia \\ 2 Faculty of Engineering, University of New South Wales, Sydney 2052, Australia \\ * Correspondence: samad.sepasgozar@gmail.com; Tel.: +61-046-962-8400
}

Received: 24 May 2019; Accepted: 25 June 2019; Published: 29 June 2019

\begin{abstract}
The construction technology market is competitive and complicated, due to the high-risk of digital technology utilisation in construction projects and the conservative character of construction companies. This complexity affects the process of job-site technology dissemination and adoption in which construction companies make decisions to purchase and utilise the new technology. The complexity is one of the reasons that many new remote technologies, positioning and locating systems, lasers and drones, 3D printing, and robots are not widely adopted in the short term, despite vendors making determined efforts to overcome this. Three objectives are investigated in this paper: (i) to define criteria for examining patterns of vendors' strategies to support technology adoption; (ii) to present fact-based evidence of different vendors' demonstration methods; and (iii) to present examples of different technology groups based on their required strategies. This paper presents the results of a longitudinal investigation of the construction technology market, including patterns of technology demonstration and a conceptual model of classifying vendors and their technologies in construction market places. The model involves the three most important factors that distinguish technology exhibitors: Physical appearance, Interpersonal relationship and Technology demonstration. Data was collected from technology exhibitions, involving randomly selected vendors. This data was analysed using hierarchical and c-means clustering techniques. The hard-clustering techniques resulted in vendors being placed in five classes based on the elements of the PIT framework. Fuzzy analysis shows how these classes fit into an underlying strategy spectrum. Understanding the strategies used in each class enables new vendors to select their own dissemination strategies based on their own particular circumstances. The practical implication of this study is to present a set of dissemination strategies to new technology stakeholders involved in Industry 4.0. The identified patterns of technology vendor strategies and the novel conceptual model contribute to the body of knowledge in technology diffusion.
\end{abstract}

Keywords: construction job-site technology; technology demonstration; green technology; heavy equipment; diffusion; technology adoption; digital construction; cluster analysis

\section{Introduction}

The construction industry is a large market for new technologies, including digital systems. The global construction technology market is estimated to be worth several billion dollars [1]. However, the process by which a technology is disseminated has been ignored in the building construction literature. The market analytics, including the technology diffusion process, is critical to manufacturers and innovators, and is frequently acknowledged in construction [2-5]. Understanding the details and sequences of the market and the process are important because the construction market is subject to 
booms and collapses. These fluctuations have a huge impact on the innovation process, including the equipment and tool manufacturers, particularly recently established vendors. Despite this, many business reports indicate that new technologies fail at a stunning rate of 40 to $90 \%$ [6,7] depending on the technology type [6-8] and due to lack of training, organisation policy, innovativeness of users, and complexity of the technology. These figures demonstrate that technology dissemination strategies, including different strategies of technology demonstration in the construction industry, are a significant phenomenon, which has been reflected in recent studies $[2,9,10]$.

Sophisticated high technologies have been created in an attempt to offer technological solutions to increase safety and productivity and the complicated challenges facing today's construction industry. Previous research $[4,11-19]$ suggests that new technologies have a large beneficial effect on overall productivity, quality and safety in construction. However, the whole industry continues to be stagnant in technology adoption and the evidence shows that it is generally resistant to change [11,20-25]. For example, the empirical data from the Melbourne Institute of Applied Economics and Social Research [26] shows that the construction innovation index is always significantly lower than all other industries. For example, CAD technology was developed in the 1960s, but its adoption by construction companies mainly took place two decades later in the US, and much later in Asia and other countries. The technology adoption lag and risk aversion to utilising the technologies, which could be called the "adoption paradox", are due to many reasons such as the uniqueness of the technologies [27,28], the variability of vendors and companies' expertise, and the nature of the industry itself [29].

Prior research about technology adoption provides an abundance of theory and evidence regarding how technology is adopted [30]. However, very little is known about how the technology dissemination process is initiated, and how the technology itself is demonstrated to the construction and mining markets. Since some technologies are commonly being used in both construction and mining, both sectors them are covered in this study, while the main focus of the paper is the building construction market.

The literature shows that there are positive impacts from the use of new and advanced technologies in construction [31-33]. However, there has been no consideration of the adoption influencers and vendor behaviour patterns. In addition, there is no understanding of the difference in demonstrating various technology groups from small hand-tools to advanced digital tools. The paper aims to present strategies used for different technology types, and vendors who are demonstrating these technologies. The paper also aims to provide examples of vendors from different classes based on their demonstration strategies which may affect the adoption process in construction. The paper has three main objectives: (i) defining the concept of technology adoption and different strategies of technology demonstration; (ii) identifying vendors' strategy patterns based on their demonstration activities in the adoption process in the market place. For example, Figure 1 shows how different vendors of heavy equipment successfully attracted many professionals in a construction TE in the US; and (iii) modelling the vendor-customer interactions by identifying key factors. This paper focuses on understanding the varieties of vendors and technologies in construction. While previous research is more industry-focused, this research is technology-oriented to present a pattern of demonstration strategies for different technologies in various market places in order to better understand the adoption process. The paper contributes to understand differences in the trajectory of the dissemination and diffusion of different technologies.

The paper proceeds as follows. First, the relevant concepts and terms of the construction technology adoption are defined and discussed. Then, the inductive method by which the dissemination process unfolds is explored, including how technology demonstrations are initiated in the construction industry. 
Temporary two-story building for one-week show

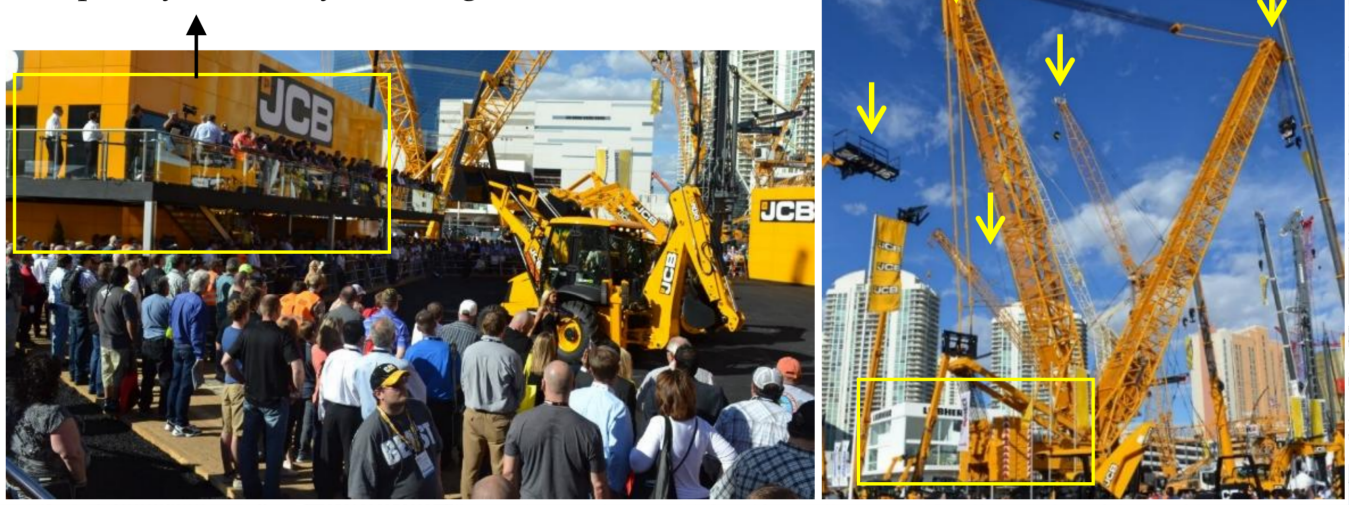

Figure 1. Vendors demonstration activities successfully attracted many professionals in a construction TE. Arrows in the second picture indicate the number of cranes on display the exhibition.

Next, data is presented from selected exhibitions, including examples of vendor strategies. Then, the Construction Technology Adoption Process (CTAP) $[4,34]$ is used to synthesise the main dissemination strategies including Physical appearance, Interpersonal relationship, Technology demonstration (PIT). Fourth, we discuss the implications of our findings, followed by our conclusions.

\section{Terms, Concepts and Theories of Technology Adoption}

The key terms used in the literature of technology adoption will be introduced in this section. Defining these terms also will create alignment in thinking of specific technologies and users' interactions in the construction field, which is interdisciplinary and borrows terms from different contexts such as information systems, engineering, sustainability, economics, marketing and management.

\subsection{Digital Construction Technology}

From the economics perspective, technology is tied to the concept of productive efficiency. However, technology refers to a broad concept that deals with the use and knowledge of tools, devices, hardware, software, materials, utensils or any specific techniques for doing a process. Jaafar et al. [29] defines technology as tools and infrastructure to support the business function in the construction context.

Jaafar et al. [29] also suggest that users should have adequate skills to use it and an understanding of and belief in the technology. They discuss the notion that enabling and supporting the successful adoption of the technology is a required process. In this case, the management, either an individual or a group, should believe in the technology and support the adoption process within the organisation.

In construction projects, the term "technology" is often used interchangeably with equipment, technical methods, specific construction operation process, specialties, materials and formworks, knowledge and tools [35]. In the present paper, the terms will be restricted to digital tools, hand tools devices, hardware, heavy equipment or machines. Table 1 shows examples of new technologies in construction including: crane equipped with programmable system, unmanned aerial systems, light detection and ranging (lidar) and laser scanners, real-time locating system, autonomous haulage system, global positioning system and radio frequency identification. 
Table 1. Selected technology types used in construction.

\begin{tabular}{|c|c|c|}
\hline Examples & Description & Applications \\
\hline $\begin{array}{l}\text { Crane equipped with } \\
\text { programmable system }\end{array}$ & $\begin{array}{l}\text { Programable systems for } \\
\text { controlling and monitoring; with a } \\
\text { remote control for controlling from } \\
\text { outside the operator cabinet; } \\
\text { Camera and anti-collision systems } \\
\text { [36]. }\end{array}$ & $\begin{array}{l}\text { Transport materials vertically and } \\
\text { horizontally. }\end{array}$ \\
\hline $\begin{array}{c}\text { Unmanned aerial } \\
\text { Systems/Vehicles (UAS/UAV) }\end{array}$ & $\begin{array}{l}\text { An aircraft without a human pilot } \\
\text { aboard used for analysis and } \\
\text { inspection of construction sites. }\end{array}$ & $\begin{array}{c}\text { For bridge inspection and damage } \\
\text { identification [37], building } \\
\text { performance, visualising heat } \\
\text { transfer [38] }\end{array}$ \\
\hline $\begin{array}{l}\text { Light Detection and Ranging } \\
\text { (lidar) and laser scanners }\end{array}$ & $\begin{array}{l}\text { A method using light in the form } \\
\text { of a pulsed laser to measure } \\
\text { variable distances [39]. }\end{array}$ & $\begin{array}{l}\text { As-built modelling }[40,41] \text {, urban } \\
\text { analytics }[42,43]\end{array}$ \\
\hline $\begin{array}{l}\text { Real-time locating system } \\
\text { (RTLS) }\end{array}$ & $\begin{array}{c}\text { A device to locate the current } \\
\text { geographic position } \\
\text { of an object (e.g., labour or } \\
\text { material) and tracking them [44]. }\end{array}$ & $\begin{array}{l}\text { To collect traffic data from } \\
\text { Site, monitor safety by tracking the } \\
\text { locations of both workers, etc. }\end{array}$ \\
\hline $\begin{array}{c}\text { Autonomous Haulage System } \\
\text { (AHS) }\end{array}$ & $\begin{array}{l}\text { With a high } \\
\text { precision GPS, milliwave radar } \\
\text { and optic-fibre gyro to control the } \\
\text { exact position of the unmanned } \\
\text { trucks [45]. }\end{array}$ & $\begin{array}{l}\text { Extend operating times, reduce } \\
\text { manpower costs and equipment } \\
\text { wear and tear, fuel consumption } \\
\text { and emissions [46], eliminate } \\
\text { human driving errors [45]. }\end{array}$ \\
\hline Global positioning system (GPS) & $\begin{array}{l}\text { A satellite-based navigation } \\
\text { system that identifies the position } \\
\text { of the electronic device [47]. }\end{array}$ & $\begin{array}{c}\text { Track the location } \\
\text { of vehicles and estimates materials } \\
\text { installation times [44]. }\end{array}$ \\
\hline $\begin{array}{l}\text { Radio frequency identification } \\
\text { (RFID) }\end{array}$ & $\begin{array}{l}\text { Reads, stores and retrieves data by } \\
\text { using a radio frequency } \\
\text { compatible integrated circuit [44]. }\end{array}$ & $\begin{array}{l}\text { Commonly used in indoor areas } \\
\text { for tracking (e.g., buildings and } \\
\text { hospitals). }\end{array}$ \\
\hline
\end{tabular}

\subsection{Technology Adoption and Dissemination}

Continuous use of a technology in a construction activity requires a successful technology adoption process. Howard and Moore [48] found that a company passes through a series of logical steps before they make the purchase decision. These steps can be mental or behavioural at the individual level, but they are more logical and based on policy at the company level. To distinguish this difference, we call it "technology acceptance at the individual (user) level", and "technology adoption at the organisation (or project) level". According to Rogers [49], adoption consists of several steps in the purchase process through which the adopter passes to make a decision to adopt or reject the innovation, or a new method or technology. Then, implementation is often considered as the last stage of the technology adoption process or a natural extension of the process [50] altering technology operational sequences [51]. In the literature, the adoption process also refers to the necessary steps to introduce a product into the daily operations of an organisation [52]. However, this paper focuses on the first steps of the adoption process, namely technology demonstration from the vendor's perspective. Our exhibition investigations and observations provide the empirical foundation upon which we develop an improved construction technology adoption and dissemination model.

Technology adoption encompasses a long and complicated process, which may be affected by technology exhibitions as moderating events. The process involves a series of complex interactions between vendors on one side, and construction companies on the other side. Previous studies relied on the Technology Acceptance Model (TAM) $[45,53]$ and the Unified Theory of Acceptance and Use of Technology model in construction [54]; however, other stakeholder roles such as vendors role and their strategies remain unexplored $[45,55]$. The literature indicates several significant differences in the 
decision-making process in the construction context compared to other industries such as smart cities, mobile banking, e-government, agriculture, manufacturers and e-learning. Anderson and Schaan [56] argued how the process might be different when the advanced manufacturing technologies are totally different to the existing construction production process. Other differences are the environment in which construction takes place [57], the number of interaction parts of the work flow, involvement of several sub-contractors and external companies, complexity and uniformity of tasks and teams to place and time, and the uniqueness of every project. While the effect of these factors on the technology adoption process should be investigated case by case, vendor strategies in the market place, particularly in technology exhibitions, should be evaluated. This paper provides observations of vendor strategies to demonstrate technologies.

\subsection{Technology Exhibition}

Technology exhibitions (TEs) are intensive market places and multibillion dollar businesses, which are significant events for facilitating the adoption process and communicating with potential adopters. The fundamental premise of exhibitions is to provide an efficient marketplace attracting potential customers for viewing new technologies demonstrated by vendors [58]. The fundamental premise of any construction TE is to provide a venue to bring together all players of the innovation market, and relevant professionals, thereby increasing the interaction between vendors and construction companies in a cost-effective way. Previous studies highlight the importance of TEs in dissemination and technology transfer for business to business marketing [59-61]. However, there is not sufficient scholarly reports from construction TEs to give deep understanding of the current practices of construction technology exhibitions.

TEs are known to be a major channel for technology transfer [62-64] and learning expeditions for potential adopters [65,66]. According to Lee et al. [67], for successful implementation of a high-technology, both sides need good cooperation in order to transfer knowledge about the operation of the equipment. Reychav [68] studied knowledge sharing in trade shows and found that TEs are important since customer-vendor relationships can be initiated or strengthened. Furthermore, a TE contributes to an on-going business relationship for a long period of time, and may increase the trust between both parties. Industry reports show that the performance of TEs are relatively successful for construction technology marketing. Previous studies have frequently highlighted that exhibitions are important tools for industrial marketing [59-61,69,70]. In addition to demonstrating vendors' know-how and their capability to transfer knowledge, they tend to actively attract visitors and support them to advance the decision process.

\section{Theoretical Framework and Gap in the Literature}

Interaction and communication between construction companies (i.e., customers) and vendors are required to carry out a deal. Holt and Edwards [71] state that machinery sales analysis ultimately supports business decisions and the sale occurs in an environment characterised with both supply and demand sides. Technology adoption including the purchasing occurs when the construction company identifies a possible solution first. Then vendors should support the customer by providing relevant knowledge and offering technology. Thus, both demand and the knowledge of the technology are the main instigator of new technology adoption. The customer-vendor paradigm finds its origin in demand conditions rather than technology push [72]. Sepasgozar and Davis [4] explains that technology adoption is not an event occurring in one day; rather, it is a process involving a sequence of consecutive phases a construction company passes through up to the implementation phase as shown in Figure 2. 


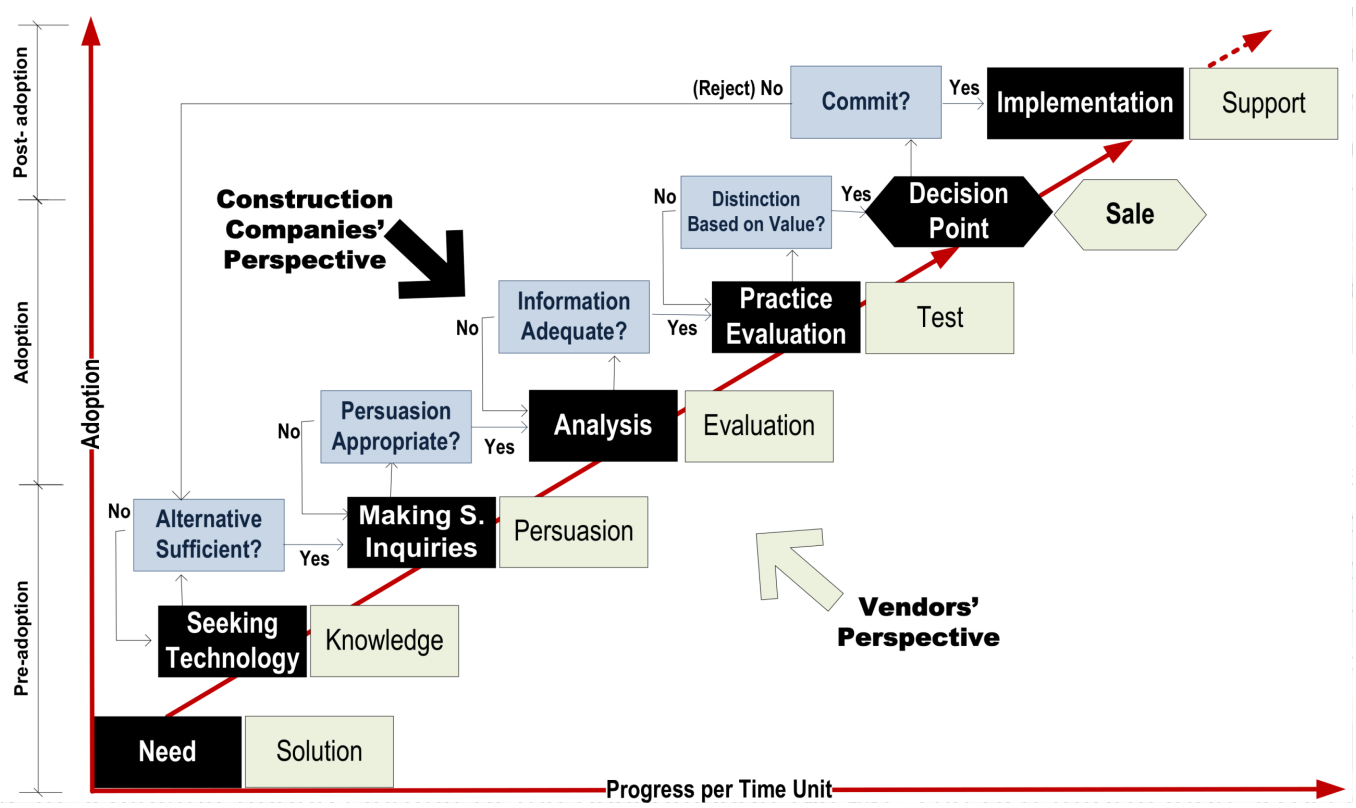

Figure 2. Details of the decision-making process based on the stages defined in CTAP.

\section{Proposed Variables and Hypotheses Development}

Technology exhibitions (TEs) are intensive market places that are critical to vendors since they can release and demonstrate their new job-site technologies. At the same time, TEs may support customers to learn about new job-site technologies and collect required information to make their decision to purchase a new construction job-site technology. Thus, analysing observations of TEs enables deep understanding of the existing patterns of vendors' strategies to support the technology adoption process. Our observations consist of field notes, videos, photos, interview records, conversations manuscripts and evidences of their activities such as visual records. In order to analyse the data, a Gauge Matrix [GM] was constructed primarily based on the TE visits, visit notes and unstructured interviews with vendors at the TEs. 38 variables were identified across four key indicators to measure vendors business behaviour at the TEs. These indicators cover booth design, communication facility, and technology attributes. The physical design of a booth is an important mechanism for grabbing visitors' attention in a TE. Large booths grab visitors' attention, and well laid out booths are more likely to draw customers in to initiate the adoption process. Thus, display appearance can be a major factor for effective exhibition marketing [73,74] and contributes to exhibition performance [59].

\subsection{Technology Attributes and Relevant Information}

Technology attributes play a crucial role in customers' decisions and the strategy of demonstrating the technology is very important. Situma [75] explains that large industrial technologies could be exhibited under controlled conditions. Complex job-site technologies usually have their own distinctive characteristics that need specific conditions to be exhibited. Vendors marketing strategies are more likely associated with technology attributes. For example, a tool vendor exhibiting a saw would use a smaller booth than a large mobile crane vendor, which needs a more spacious booth to demonstrate functionality of the equipment, compatibility, attachments, and engine parts. In addition, the leading vendors in each category may demonstrate a series of technologies for different tasks.

Most of visitors were interested in product information, with the chief reason given for attending a TE being to search for a new technology. A TriComB2B [76] survey shows that $27 \%$ of purchasing persons respond that trade publications are important information sources for purchase decisions. Vendors provide more facilities and training technologies to make it easy to understand, compare, and choose. Vendors are willing to provide competent knowledge and transfer technical information to all visitors from each stage of the adoption process looking for opportunities provided by a new 
product. According to Geroski [77] vendors are responsible for facilitating the flow of information about new technologies for marketing. Codified knowledge can be found in technology vendors' manuals. Therefore, thirteen different tactics relevant to technology attributes and disseminating information such as posters and demonstrations are listed in.

Using the measures (refer Section 5), vendors were separately scored for each variable. Then, the cluster analysis algorithm was applied to recognise patterns in the sample of vendors and technologies.

\subsection{Vendors Interactions, Communication and Networking Facility}

One of the main reasons for vendors to attend a TE is to communicate with potential customers. They invest in creating a suitable area for communication and demonstrating their technologies. In general, both communication channels and avenues from small to large are critical in the dissemination process. A short-term benefit of the communication is to initiate the adoption process at Technology Exhibitions. The adopters get the opportunity to extend their networks of vertical and horizontal relationships to acquire deep and tacit knowledge in each stage of the Construction Technology Adoption Process (CTAP) [4]. The communication facility assists the adopters to get technical or interactive information or build a relationship with technology vendors for future contact. Vendors deploy a wide range of communication sources to make a convenient environment to invite customers, transfer relevant information, support the decision makers, and boost the image of the brand. All these strategies support the idea that the process of technology adoption is actively supported by vendors, which is called dissemination rather than the passive practice called diffusion [78]. According to Hansen [59], vendors at the show communicate to build corporate image and reputation while they create technology interest and transfer knowledge. Therefore, communication is critical for vendors who need to transfer more information related to the adoption process.

There are two networking types that can be important to be identified in the technology adoption process: vertical networking and horizontal web. Vertical networking refers to the customer's relationship with existing and active vendors. The horizontal web refers to the customer's relationship with other stakeholders such as associations, partners or regulators. According to Lee et al. [67], in order to transfer technology, tacit knowledge is very important and it can be transferred through a close relationship between the two sides. The literature shows that a strong relationship between vendors and customers, a so-called strong tie, has positively contributed to the CTAP, and is more likely to lead to sharing of sensitive information $[79,80]$. This relationship is even more significant especially for highly advanced equipment that is more complex than conventional products. Because, complexity is an inhibitor for successful adoption, although, as technology advances it becomes more complex and sensitive to operate [81]. When technologies become complex to understand a number of experts from the vendor's organisation and the technology manufacturer are usually available to respond to visitor enquires. For example, size and purpose of backhoe buckets vary between equipment types. It will be even more complex when the new backhoes are equipped with digital boards and controlling systems. Therefore, vendors, especially those who offer complex technologies, employ different tactics to facilitate effective communication, such as larger conversation rooms and virtual reality.

Conversation to exchange rich information and written documents known as lean information are two major information flows for the adoption which could be successful in a conventional environment. The literature suggests that the information flow and communication facilitators are measured by various variables such as media, word of mouth $[77,82,83]$, face-to-face conversation $[73,84,85]$, number of salespersons [86], media and print mode, since they may affect the adoption process [78]. lists several key variables which were used to measure vendors' activities in order to facilitate communication for the purpose of adoption at TEs [78].

Previous studies tended to classify technologies in terms of productivity [15]. However, there is not any reliable or clear classification of different technology types in construction. The TE observations inspire the idea that there are similarities among some vendors within a proposed cluster, while significant differences among clusters of vendors exist. However, the pattern of vendors' differences 
is not understood, which may have significant impacts on the success of commercialisation and technology transfer. Therefore, a numerical measurement of the vendors marketing activities at the TEs is required to explore any existing patterns of vendor strategies in the construction market.

Construction vendors appear to employ different strategies to disseminate job-site technologies in the tight competitive construction technology market. These strategies vary in terms of major factors such as physical display [87], communication channels [49,88,89], technology demonstrations and other sources of capability information $[59,77,90]$. The question is whether these strategies can be combined into arbitrary assemblages. This paper hypothesises that there are various distinct patterns of consistent strategies and that each vendor will select one of these patterns. This paper also identifies several patterns of strategies utilised by vendors. If this hypothesis is true, then the pattern of strategies chosen by vendors would be strongly influenced by the characteristics of the technology that the vendor is selling. For example, the way that a vendor tries to communicate with customers to share information about a case technology such as a hand screw gun will be very different to the way that they try to communicate an advanced payload truck. In attempting to sell the screw gun, the vendor will focus on demonstrating the equipment to the potential customer, which can be done on a simple counter with a few physical props (such as some screws and a block of wood). However, the truck is more difficult to demonstrate because it is significantly larger, has more features that cannot be seen (such as a Hi-tech roll over protection system), and the details of ongoing maintenance is a greater factor in the customer's purchase decision. Thus, this paper also hypothesises that there are patterns of vendor strategies that align with classes of products.

The second hypothesis is that the pattern of strategies chosen by each vendor will be strongly influenced by characteristics of the technology that the vendor sells. For example, the way that a vendor would communicate with customers to share/transfer information about a hand screw gun will be very different from the way that they would communicate about an advanced payload truck. In attempting to sell the screw gun, the vendor will focus on demonstrating the equipment to the potential customer, which can be done on a simple counter with a few physical props (such as some screws and a block of wood). However, the truck is more difficult to demonstrate because it is significantly larger, has more features that cannot be seen (such as a Hi-tech rollover protection system), and the details of ongoing maintenance is a greater factor in the customer's purchase decision. This would appear to cause vendors of similar products to use similar sales strategies and have similar resource allocations. However, this needs to be verified. Thus, this paper also hypothesises that there are patterns of vendor strategies that align with classes of products.

This paper to investigate aspects of the technology which passively affects the process of the technology adoption such as inducement, trial type, purchase method and implementing assessment. It is related to the nature of the technology rather than the level of advancement of the technology. It is hypothesised that vendors' strategies at the market place are associated with the technology character. It considers whether specific strategies are imposed by the characteristics of the technology. For example, safety features of a loader should be extensively presented to the customers, while software customers have less sensitive to safety features of the software. According to TriComB2B [76], $50 \%$ construction customers are concerned about safety features of the technology, while only $23 \%$ customers in information technology (IT) are concerned about it. Thus, it is proposed that there are patterns of requirements activities of activities to facilitate marketing of each technology type. The hypothesis is that each technology type follows a specific procedure of technology dissemination in construction.

\section{Research Methodology}

The main scope of this research is to evaluate the technology dissemination process in the construction industry and develop a conceptual model. In order to record the scientific observation of technology diffusion and dissemination, selected Technology Exhibitions (TEs) were visited, and qualitative data were collected from vendors that provide a variety of common and cutting-edge 
construction technologies [78]. Criterion and sequential [91,92] methods were used to select experienced participants for interviews, in order to gain the maximum amount of rich data from the interviews. This method was adopted because the interview aim was elicitation of facts rather than individual behaviour [93]. The first-hand data was collected by attending several TEs or industry gatherings in Sydney, Adelaide, Melbourne, Brisbane and Perth, and similar events in North America. Participants from both sides of the process (i.e., customers and vendors) were chosen in order to validate the findings of each group using data triangulation methods [94,95].

Data including photos, unstructured and semi-structured interviews, exhibition directory books, all exhibition hall plans, catalogues and exhibition papers, and specifications were collected. Examples are shown in Figure 3. In addition to conversations with vendors and visitors, vendors' web pages on the exhibitions' official website and their own official websites were visited in order to get related information such as company size, type of information, and type of product. According to Belk [96], visual ethnographic methods are widely used in social sciences, such as architecture, to generate theory. In addition, an interdisciplinary method of understanding and contextualising emerges from critical visual analysis, which would be difficult to generate with other forms of data $[96,97]$. The predominant use of visual photos used in consumer research as experimental stimuli assists in achieving understanding of the phenomenon $[96,98]$. The rich information associated the adoption activities were collected and 38 measurable variables were defined and used for analysing the TE data sets using NVivo's image cataloguing functionality.



Figure 3. Different strategies to collect qualitative data from the technology dissemination process and analyse them in NVivo.

Then, photos taken of vendors' booths, showing their exhibited technologies using different demonstration strategies, were analysed. According to Van Leeuwen and Jewitt [99], content analysis 
of photos allows researchers to make quantitative generalisations. He also says that schematic and simplified versions of empirical data could be used to support the sociological argument.

Since this paper aims to classify vendors into groups with similarities in their dissemination strategies, the most appropriate type of analysis is cluster analysis. In order to explore the existing groups of vendors in the construction technology market based on the criteria shown in Table 2, different cluster analysis techniques are employed. The clustering approach is prevalent for analysis of multivariate data [100]. According to Huang [101], objects in the same cluster of vendors are more mathematically similar to each other than objects in different clusters according to some defined criteria. In this study, first partitional clustering algorithms are employed for classifying all vendors based on their adoption behaviours. Then, a hierarchical clustering algorithm recursively finds nested clusters in agglomerative mode [100] within each vendor class, because this algorithm is useful for small groups of data. According to Zhao et al. [102] hierarchical clustering solutions provide a view of the data at different levels of abstraction. After which, the same procedure is utilised using data from a different TE data set to validate the finding.

Different TEs were selected to ensure coverage of most construction technologies, including tools, drilling rigs, cranes, earthmoving equipment and plant. The exhibitions were visited to gather data from vendors who provide a variety of construction job-site technologies. Information collected from TEs include: over 10,000 photos from their booths and demonstrated technologies, exhibition directory books, layout plans of the exhibition's halls and booths (refer to Figure 3), official websites to obtain company background and technology details; technology specifications, catalogues, notes and transcriptions of vendor interviews and exhibition papers. In order to explore technology in-depth data and support our observations, we employed semi-structured interviews (refer to Figure 4), because of their flexibility to obtaining deep understanding [103]. This research strategy enables the description of the dissemination and adoption process and collect evidence of technology demonstration, and production of new insight [104]. By interviewing both the customer and vendor, we can integrate their perspectives into a larger picture and recognise commonalities [105]. We analysed the data using thematic analysis and open coding techniques, as reflected in grounded theory methods [106] and the Gioia method [107]. The results of the interviews were presented and discussed by Sepasgozar et al. [30,45,108].
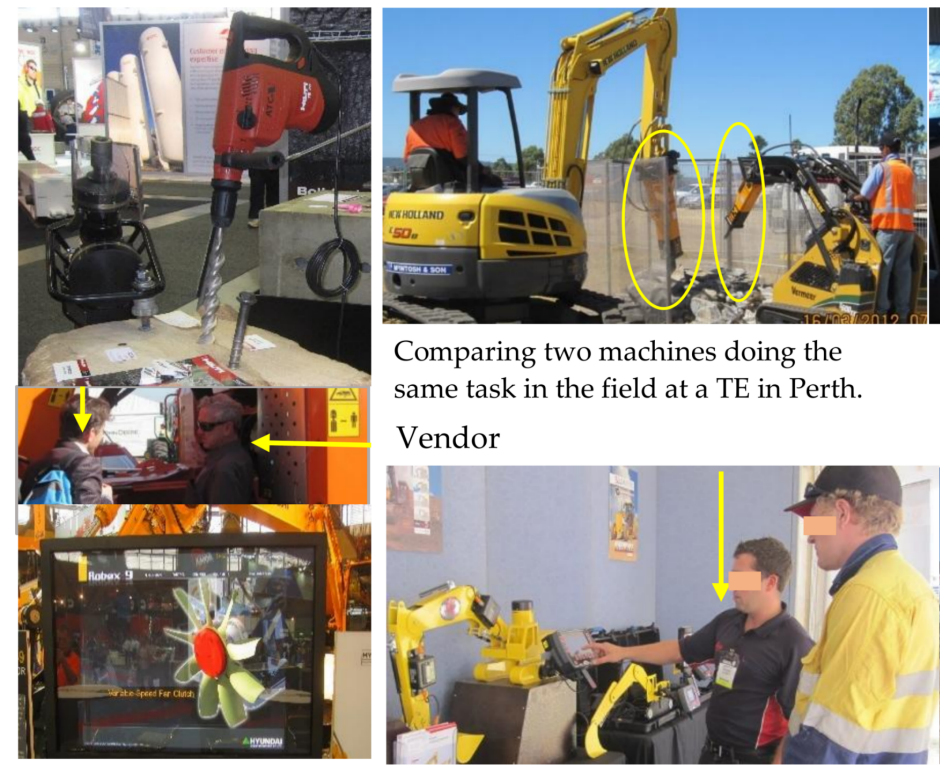

Using models for demonstrations
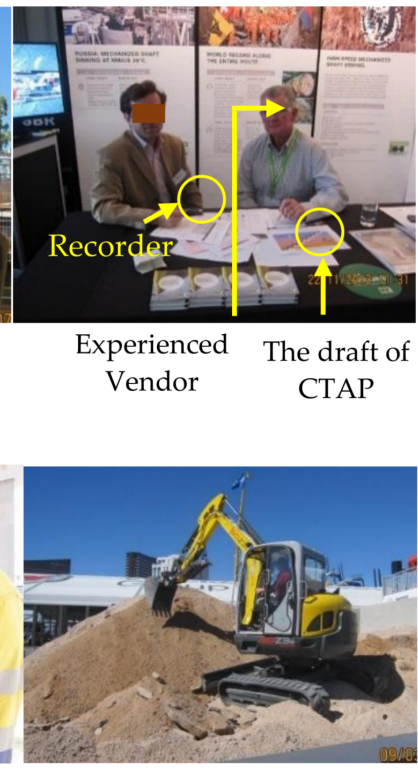

Field demonstration in a TE

Figure 4. Collecting data using the prolonged engagement strategy [4] from different TEs, where vendors used various demonstration strategies. 
Table 2. Measurement scale matrix for selected variables.

\begin{tabular}{|c|c|c|c|c|c|}
\hline Score (Rank) & 1 & 2 & 3 & 4 & 5 \\
\hline Booth size & $0-35$ & $36-70$ & 71-199 & $200-499$ & 500 and more \\
\hline $\begin{array}{l}\text { Booth designed } \\
\text { area }\end{array}$ & all not designed & $<36$ & $37-80$ & $81-100$ & $>100$ \\
\hline $\begin{array}{c}\text { General booth } \\
\text { type }\end{array}$ & not designed & basic designed & basic designed & $\begin{array}{l}\text { upgraded } \\
\text { design }\end{array}$ & unique design \\
\hline $\begin{array}{l}\text { Conversation } \\
\text { room }\end{array}$ & no & $\begin{array}{l}\text { a part of inside } \\
\text { space }\end{array}$ & $\begin{array}{l}>1 \text { spot for } \\
\text { Conversation }\end{array}$ & special space & extra room \\
\hline $\begin{array}{c}\text { Number of sale } \\
\text { person }\end{array}$ & $1-2$ persons & $3-5$ persons & $6-8$ persons & 9-12 persons & $>12$ persons \\
\hline $\begin{array}{c}\text { Number of open } \\
\text { sides }\end{array}$ & - & 1 & 2 & 3 & 4 \\
\hline Wall height & & $<2 \mathrm{~m}$ & $2.1-3$ & $3.1-4$ & $>4$ \\
\hline Table position & Front & Back & Side Perimeter & Middle & Random \\
\hline $\begin{array}{l}\text { Lighting and } \\
\text { electricals }\end{array}$ & N/A & normal & $\begin{array}{l}\text { light focused } \\
\text { on the product }\end{array}$ & extra lighting & $\begin{array}{l}\text { designed color } \\
\text { lighting }\end{array}$ \\
\hline Brand maturity & $\begin{array}{l}\text { unknown or } \\
\text { new }\end{array}$ & $\begin{array}{l}\text { known by local } \\
\text { people }\end{array}$ & $\begin{array}{l}\text { known by some } \\
\text { experts }\end{array}$ & $\begin{array}{l}\text { known by } \\
\text { experts }\end{array}$ & $\begin{array}{c}\text { known by most } \\
\text { of users }\end{array}$ \\
\hline $\begin{array}{l}\text { Asset value (* } \\
\text { 1000) }\end{array}$ & $<\$ 9$ & $\$ 10-29$ & $\$ 30-59$ & $\$ 60-199$ & $>\$ 200$ \\
\hline $\begin{array}{l}\text { Number of } \\
\text { exhibited } \\
\text { technologies }\end{array}$ & 1 to 3 & 4 to 6 & 7 to 10 & 11 to 15 & $>15$ \\
\hline $\begin{array}{c}\text { Technology } \\
\text { demonstration }\end{array}$ & N/A & simple show & $\begin{array}{l}\text { special demo- } \\
\text { static }\end{array}$ & $\begin{array}{c}\text { dynamic, } \\
\text { virtual demo }\end{array}$ & $\begin{array}{c}\text { live } \\
\text { demonstration }\end{array}$ \\
\hline $\begin{array}{l}\text { Presenting } \\
\text { potential of } \\
\text { technology }\end{array}$ & N/A & simple show & $\begin{array}{l}\text { showing the } \\
\text { capability }\end{array}$ & $\begin{array}{l}\text { maximum } \\
\text { capability }\end{array}$ & $\begin{array}{l}\text { interactions } \\
\text { with other } \\
\text { machines }\end{array}$ \\
\hline $\begin{array}{l}\text { Technology } \\
\text { models }\end{array}$ & N/A & $\begin{array}{l}\text { one simple } \\
\text { model/Parts }\end{array}$ & $\begin{array}{l}\text { Handicrafts/ } \\
\text { models }\end{array}$ & $\begin{array}{l}\text { cut/section } \\
\text { model }\end{array}$ & $\begin{array}{l}\text { site model/ sort } \\
\text { of products }\end{array}$ \\
\hline Showcases & N/A & $\begin{array}{l}\text { Simple/table for } \\
\text { cases }\end{array}$ & short glass case & tall glass case & $\begin{array}{l}\text { designed glass } \\
\text { case }\end{array}$ \\
\hline Stand displays & N/A & $\begin{array}{c}\text { simple } \\
\text { brochure stand }\end{array}$ & $\begin{array}{l}\text { folding/swing } \\
\text { up stand }\end{array}$ & $\begin{array}{l}\text { designed } \\
\text { stands }\end{array}$ & shelves \\
\hline Number of posters & $0-1$ & $2-3$ & $3-4$ & $4-5$ & $>5$ \\
\hline Poster size & $<\mathrm{A} 2$ & $2 * \mathrm{~A} 2$ & $3^{*} \mathrm{~A} 2$ & $5^{*} \mathrm{~A} 2$ & $>5 \mathrm{~A} 2$ \\
\hline Poster content & $\begin{array}{l}\text { product } \\
\text { series/model- } \\
\text { photo }\end{array}$ & $\begin{array}{l}\text { key aspects- } \\
\text { product } \\
\text { dimension }\end{array}$ & $\begin{array}{l}\text { specific } \\
\text { technology } \\
\text { photo }\end{array}$ & $\begin{array}{l}\text { product } \\
\text { capacity }\end{array}$ & $\begin{array}{l}\text { product full } \\
\text { specification } \\
\text { /in-use }\end{array}$ \\
\hline $\begin{array}{c}\text { Advertising } \\
\text { material print out } \\
\text { brochure }\end{array}$ & N/A & flyer & $<5$ & $5-8$ & $>8$ \\
\hline $\begin{array}{c}\text { Vendor catalogue } \\
\text { hand out }\end{array}$ & $\begin{array}{l}\text { general } \\
\text { Tech/brand }\end{array}$ & $\begin{array}{l}\text { technology } \\
\text { written } \\
\text { explanation }\end{array}$ & $\begin{array}{l}\text { photo- specific } \\
\text { series- } \\
\text { separately }\end{array}$ & $\begin{array}{l}\text { Eng. sketching- } \\
\text { graph }\end{array}$ & $\begin{array}{c}\text { in-use } \\
\text { sketching- } \\
\text { performance }\end{array}$ \\
\hline $\begin{array}{c}\text { Video and } \\
\text { Visualisation }\end{array}$ & N/A & $\begin{array}{l}\text { audio/a laptop } \\
\text { or computer }\end{array}$ & video $\mathrm{LCD}$ & $\begin{array}{l}\text { simulator / } \\
\text { videos }\end{array}$ & $\begin{array}{l}\text { live noise- } \\
\text { product noise } \\
\text { and } \\
\text { performance }\end{array}$ \\
\hline $\begin{array}{c}\text { Product } \\
\text { Advertising }\end{array}$ & General & $<3$ cases & 4-6 cases & $7-10$ cases & $>11$ cases \\
\hline Number of Staff & $1-2$ persons & $3-5$ persons & $6-8$ persons & 9-12 persons & $>12$ persons \\
\hline Function of Staff & advertiser & sale person & expert & mechanic & $\begin{array}{c}\text { managers and } \\
\text { technicians }\end{array}$ \\
\hline
\end{tabular}


The literature highlights the fact that a multitude of strategies are used by vendors for disseminating job-site technologies at TEs [78]. For example, the literature claims that physical appearance is one of the major strategies used to disseminate technologies [75]. Interactions between the vendor's staff and the potential customers is also claimed to be a key factor because communication and strong customer-vendor relationships $[67,109]$ positively contribute to adoption by sharing information [49,79,80], facilitating technology transfer [59] and building rapport [110]. These factors have been broken into individual variables (refer) for use in the cluster analysis.

It is proposed that vendors may follow different strategies which can be categorised into several specific patterns of dissemination strategies. Therefore, pattern recognition algorithms might be useful for analysing the data to try to identify different disseminating and marketing patterns. Three clustering algorithms, hierarchical, k-means and fuzzy c-means (FCM), were used to give both hard and soft compartmentalisation clusters. Sepasgozar, Davis [78] used the FCM clustering method, which is useful for seeing the spectrum of strategies that vendors use, and they also used K-means clustering, which is useful for grouping individual vendors into clusters. The k-means clustering was used to find out whether different vendors in each cluster shared activities and characteristics that might account for the common scope/extent of business activities associated with that cluster [78]. The similarities between vendors in the same class are high, while those between vendors in different groups are low. This classification assisted in identifying technology groups that could be affected by the vendors' strategies to support the decision makers. This pattern can be called the vendor-technology paradigm, which most likely affects the visitors' decision to purchase the technology or ignore it. In order to hierarchically and visually analyse the pattern within a class of vendors, Hierarchical cluster analysis is employed when each class members are identified by the K-means algorithm.

\section{Data Analysis and Results}

This section summarises the identified purposes of attending different TEs by vendors and visitors. Vendors employ different strategies to present their job-site technologies in TEs such as different booth designs, interactions and relationships with customers, and the way they demonstrate their technologies. The decision to purchase a major piece of construction jobsite technology is not a simple transaction process. Instead, it is more like the start of a relationship, because customers need the vendor's experience of using technologies and also their after sales services. Construction site job technologies will always require replacement of wear and spare parts, and it is much more common to have the vendor involved in maintenance. Thus, they will focus on whether they are confident that the vendor will both be around to support them (i.e., not have gone out of business) and have a good reputation for actually supplying this support in a timely manner. The vice president of a pump company explains:

"Customers check all the technical data. [...]They check technology, cost of machine per year. Very often they ask the sub-supplier [local dealers] can you do a spare and wear parts proposal for one year when the pump is working $8000 \mathrm{~h}$ per year. They analyse the technical, commercial, delivery time, then they come to a decision. It's not the cheapest that gets the order, the most reliable gets the order. Technology and delivery time: this is important." (26.20 \#cn1)

The interview data shows that equipment rental companies are very sensitive to brands and relationship with vendors. For example, a rental company discusses that brand makes customers confident; because they trust the brands that they know and have experience of. Another customer says that "brands represent a lot of things" and then explains: "some brands provide superior service, and parts availability ..." "However, the interviews show that when customers think of a brand they not only think about the equipment itself and its capabilities and quality, but also the relationship that they can build with the vendor and the after sales service that they will receive. The interviews show that customers are attracted to prominent brand name technologies, even if they are not able to afford to purchase them. They will then use the prominent brand name technology as a benchmark for 
comparing more affordable technologies. The interviewees from equipment rental companies have a particular preference for purchasing prominent brand name equipment, and developing long term relationship with the supplies, because they can get better services and cheaper prices compared to what is offered to smaller contractors.

According to Reychav [62], TE is a unique occasion which enables collaboration between two sides in a limited time and space which may be characterised by its dynamic nature. In construction, the vendor-construction company relationships are crucial instead of just a transaction-specific investment. For example, in a tunnelling or bridging project, both contractors and tunnelling technology vendors should collaborate and cooperate for redesigning of technology, production scheduling and knowledge exchanges throughout their relationship. Reychav [68] studied knowledge sharing in a trade show and concluded that customer-vendor relationships initiated or strengthened in a TE contribute to an on-going business relationship for a long period of time after TEs. In this term, the vendors' role to take appropriate strategy to support the adoption process is crucial. According to Godar and O'Connor [84], in the traditional type of interaction buyers contact salespersons, while in TEs, the interaction is more under the control of the vendor. In fact, vendors take different strategies to influence the decision makers (Figure 5). Thus, TEs are important places to study patterns of vendor-customer interactions, and to explore how they build relationships, their business behaviour, and identify a technologies typology.

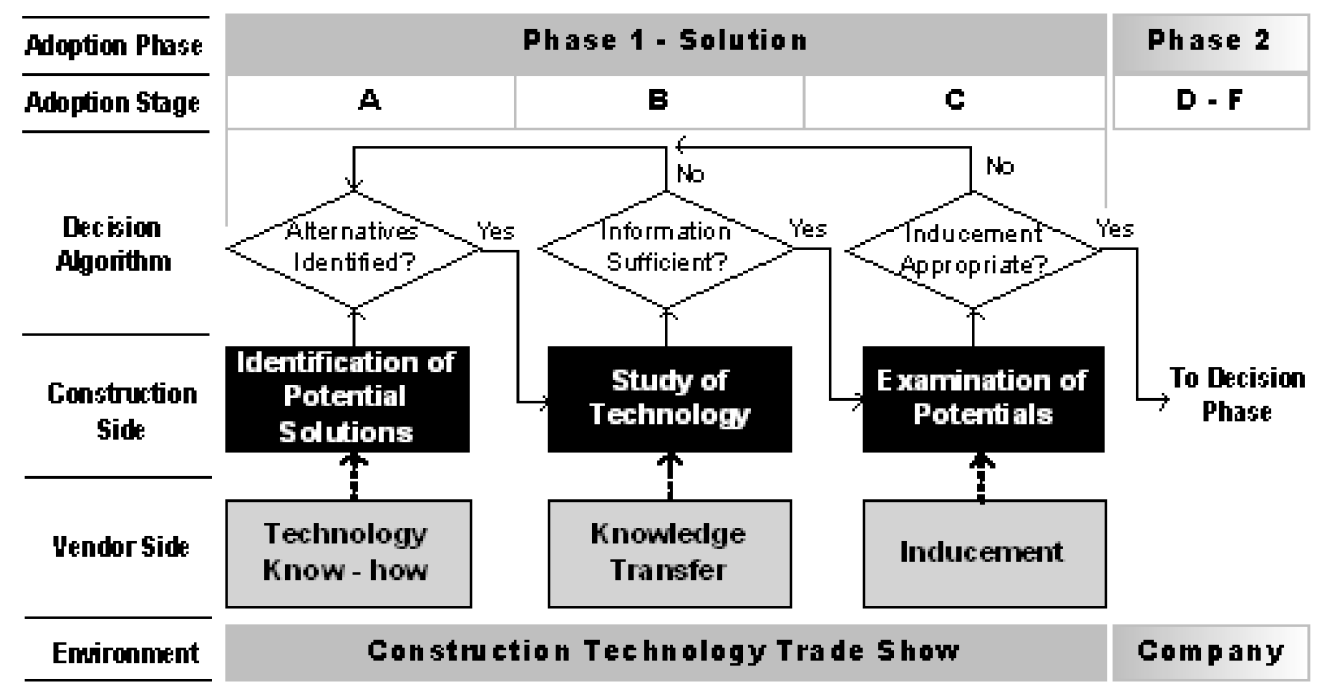

Figure 5. The process of technology adoption in the first stages at TEs.

According to Hommels et al. [111], knowledge is crucial for customers to successfully use a new technology. They attend TEs to identify possible solutions for improving their current practice by learning from new methods and technologies and collecting relevant information for making decisions to address their challenges or needs. Several participants pointed out that without the previous identification of a need, the adoption process would not be launched in a construction company. This observation is in line with the problem solving theory discussed by Felin and Zenger [112], and a direct extension of identifying the state of the customer.

For further analysis, the data collected from two TEs were carefully prepared for statistical analysis. The hierarchical analysis method was employed to group vendors. In order to create these dendograms each factor was normalised to have a mean of zero and a standard deviation of unity. Principle component analysis was used to find the major components. The components were then used in hierarchical clustering analysis using Ward's method. This involves starting with all vendors in separate clusters. Step 1 joins the closest two vendors into a single cluster, with the rest still in their own clusters. Each subsequent step involves joining the vendor that is next closest to another vendor with the cluster that that vendor belongs to. 
In both TE1 and TE2 similar hierarchies were found for the first 5 levels. In each case there is a large horizontal distance between 5 clusters and 6 clusters, and the range for which 5 clusters applies is in approximately the same rescaled distance range. Furthermore, the branching pattern for the 5 clusters is the same in both data sets as can be seen in Figure 6.
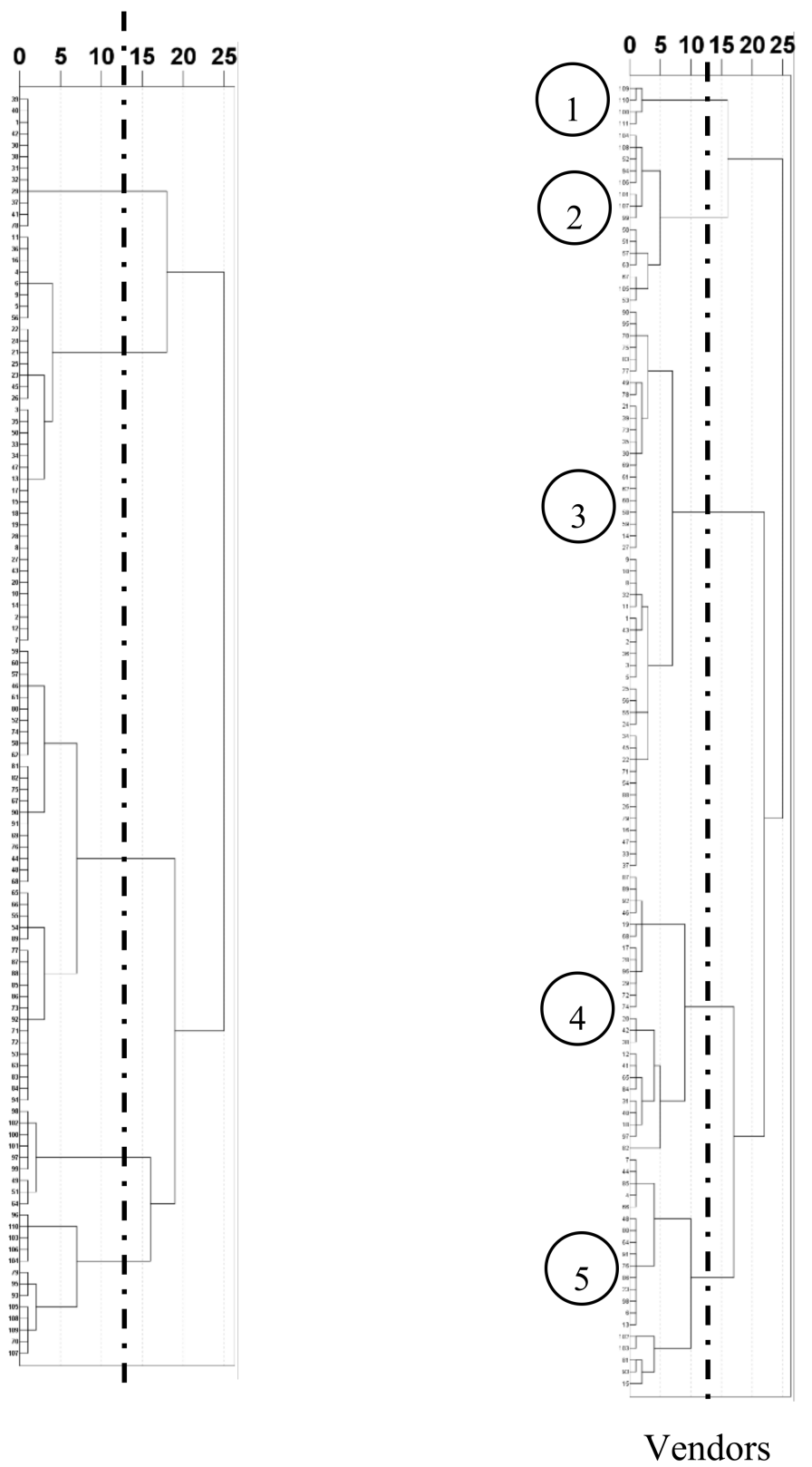

Figure 6. Dendograms using Ward Linkage on two TEs.

In order to examine the adoption activities or strategies, booth attributes [73] such as booth size, designed area, location, number of closed or open sides of the booth, general design type, flooring, wall and hanging are considered as measurements of vendors' passive strategies. The five clusters are similar to those found by Sepasgozar et al. [78] and summarised in Table 3. 
Table 3. Examples for each cluster.

\begin{tabular}{|c|c|c|}
\hline Class & Strategy & Attitude \\
\hline Class A & $\begin{array}{l}\text { booth design area; food catering; } \\
\text { live celebrities; > } 12 \text { booth staff; } \\
\text { technology live demonstration }\end{array}$ & $\begin{array}{l}\text { Focused on brand awareness, provide } \\
\text { references from previous customers at } \\
\text { booth, developed relationships, made } \\
\text { engineers and after sales persons available, } \\
\text { provided conversation areas, established an } \\
\text { anchor booth. Could be called "brand } \\
\text { vendors" [113] or "leader vendors" [65]. } \\
\text { Attractive to potential adopters to } \\
\text { communicate with [113]. }\end{array}$ \\
\hline Class B & $\begin{array}{c}>165 \mathrm{M} \text { far from main distance; } \\
\text { located close to class A vendors; } \\
\text { three sides of their booth open; } \\
\text { upgraded designed; } 4 \mathrm{M} \text { product } \\
\text { height. }\end{array}$ & $\begin{array}{l}\text { Relatively spacious booth without dynamic } \\
\text { and extensive environment. Could be called } \\
\text { "niche/defender vendors". Established } \\
\text { spacious space for communication; used } \\
\text { unique colour for both and product. }\end{array}$ \\
\hline Class C & $\begin{array}{l}\text { 2 3 sides of their booth open; } \\
\text { upgraded designed booth; big size } \\
\text { posters. }\end{array}$ & $\begin{array}{l}\text { Peninsula-type booth [113]. } \\
\text { They want to be differentiated than } \\
\text { competitors of class B or D. Made } \\
\text { conversation special space available. }\end{array}$ \\
\hline Class D & $\begin{array}{c}\sim 71 \text { to } 199 \mathrm{M}^{\wedge} 2 \text { booth size; sited } \\
\text { close to a road; close to class B or C } \\
\text { located; } \\
\text { two sides of booths open; } \\
2 \text { M wall high; known by } \\
\text { professionals. }\end{array}$ & $\begin{array}{c}\text { Brand shopper for tools and light } \\
\text { equipment that could not be offered by class } \\
\text { A vendors, are targeted. Because brand } \\
\text { maturity of these vendors is greater than } \\
\text { class E vendors. This cluster is comparable } \\
\text { with class E because of the similarity of } \\
\text { their technologies. }\end{array}$ \\
\hline Class E & $\begin{array}{l}\text { Used table/desk/cases for } \\
\text { technology; used less socialisation; } \\
\text { 4-6 product lines at booth; used } \\
\text { one simple model or section. }\end{array}$ & $\begin{array}{l}\text { Utilised low-cost strategies made awareness } \\
\text { of existence, used basic configurations, } \\
\text { include entrepreneur vendors; the smallest } \\
\text { booth size distinguish them; according to } \\
\text { Gopalakrishna [113], niche tool shoppers } \\
\text { are interested to these vendors. }\end{array}$ \\
\hline
\end{tabular}

\section{Theoretical Model Development for Technology Dissemination}

Applying the trade show literature to the strategies utilised by construction technology vendors at TEs offers a new approach to understanding dissemination in the construction industry. The dissemination process in construction has not been empirically investigated previously, and hence the theory describing this process is undeveloped. Major construction technologies are very expensive, and the wrong choice will result in poor project performance, leading to large financial losses. Consequently, decisions regarding the adoption of new construction technologies follow lengthy processes, in some cases extending for over a year. This adds to the slow diffusion rate in construction. It means that widespread adoption of new technologies can take several years in the construction industry to be achieved. However, vendors may not be able to wait for such a long time for their market to be established, leading to either the vendor going bankrupt or abandoning the product. Vendors not only rely on the diffusion process (let it happen), but instead spend a great deal of money and proactively apply a variety of dissemination strategies (make it happen). Developing interpersonal relationships during dissemination increases the likelihood that customers will decide to adopt the technology. Due to the limited market for construction technologies vendors seek targeted marketing opportunities. One critical marketing channel used for construction technologies is technical exhibitions. Results from the present study show that vendors have similar dissemination strategies in each cluster (see [78]) offering similar technologies. 
One way to understand vendors' strategies in these clusters and classes is to separate the strategies into three categories as shown in Figure 7: (a) Physical appearance, (b) Interpersonal relationship, (c) Technology demonstration. The PIT framework is offered primarily as a way of structuring the results, although the discussion herein will provide support for its general validity.

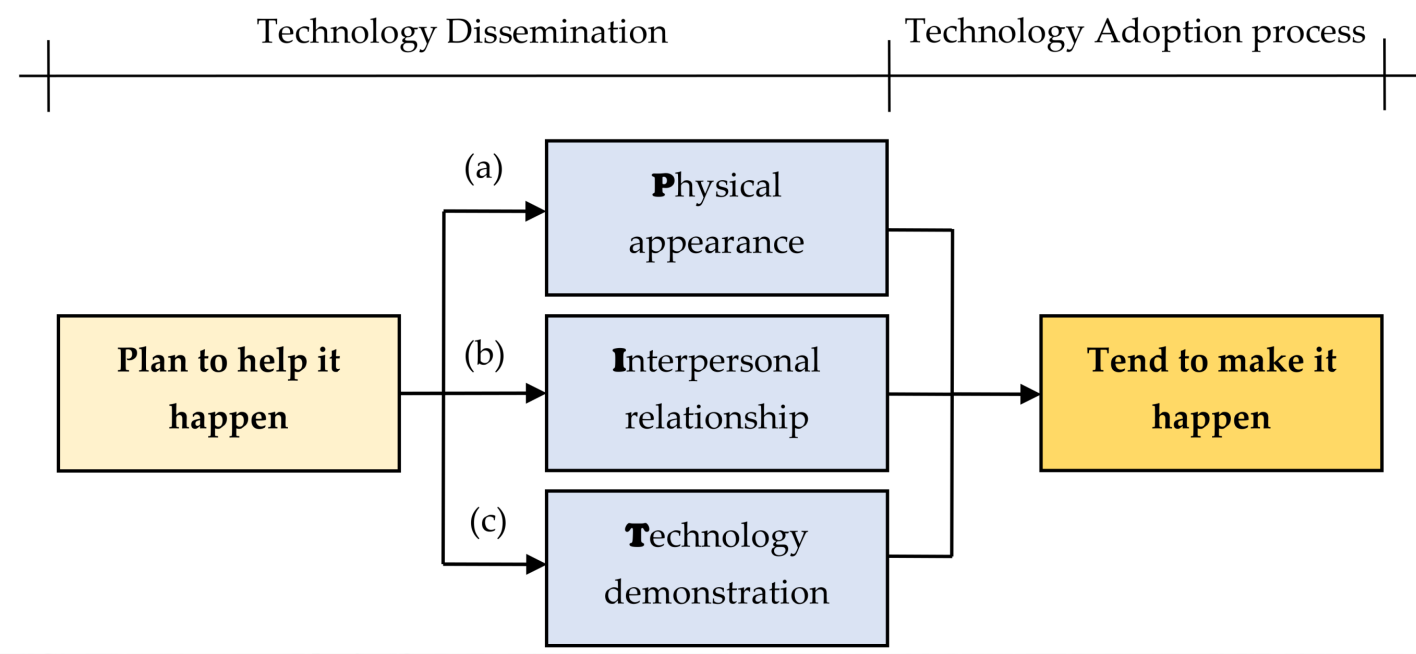

Figure 7. The PIT framework for construction technology dissemination strategies. $(\mathbf{a}-\mathbf{c})$ refer to the dissemination strategies discussing in the next section.

\subsection{Physical Appearance}

Vendors allocate many resources to design and establish a booth in a TE to attract visitors. Using physical aspects of the booth for marketing is called impersonal booth promotion in the trade show literature [86] and serves to attract the target audience [58]. These aspects include better booth location, more entrance and space, and more sophisticated booth design including colour, light and materials used to establish the booth. Lee and Kim [114] state that bigger booths attract more potential customers to visit, and also result in increasing exposure of the technology to customers. The observations show that vendors in Class A focus on the characteristic of their booth and spend much more resources on their booth design compared to the other clusters of vendors (Figure 8).

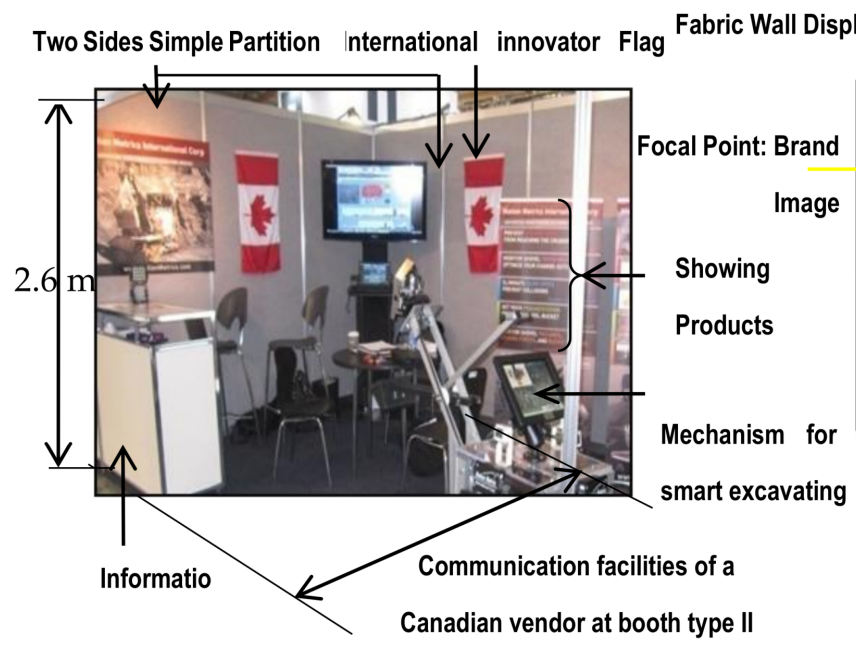

a) Booth Type (Cluster D): Standard Box

b) Booth Type (Cluster A): Branded Design

Figure 8. Different classes (cases and examples) from TE observations including vendors activities at the early stage of the technology adoption from different classes. (a) standard design, (b) Hitachi's large and with artistic design, World Class Hydraulic Excavator Hitachi. 
Communication channels are critical in the technology adoption process, because the information about vendors and their technologies can travel through the communication sources to the potential customers. It has been frequently cited that better communication would increase the success of dissemination and may facilitate the adoption process. Lee et al. [85] did a survey on IT adoption in the field of internet banking and suggested that communication factors are important predictors of the adoption. They also conclude that conversation (rich information) and written documents (lean information) are the two major communication modes [85]. Different communication channels such as word of mouth $[77,82,83]$, face-to-face conversation $[73,84,85]$, media and print mode are reported as communication sources. TE observations showed that vendors use a variety of strategies to communicate with potential adopters. A number of experts from the dealer office or manufacturer were available to respond visitors' enquires, provide more information, and possibly build relationships with potential customers. This will be discussed in the following section. For example, size and purpose of backhoe buckets vary between equipment types and may affect the productivity and the benefits of customers. Vendors offer a specific product which potentially fits the task as the "best" solution for a particular customer at this stage by highlighting the capability of their job-site technologies and offer deals which customise the product or provide a versatile tool. In addition, a potential customer needs more information and evidence about the machine. Since booths usually are small sized and there are limitations to show how a technology works, vendors tend to use virtual environments and advanced visualisation technologies to show how their technology is working in an attractive way. Figure 9 shows examples of virtual reality and visualisation tools recently used by vendors in different TEs. As one would expect, large number of visitors came to gather technical information. Codified knowledge can be found in technology suppliers' manuals. However, the booth provides a direct channel for face-to-face contacts between experts and a potential customer with a problem or a need. However, vendors also provide competent knowledge and technical information to visitors looking for opportunities provided by a new job-site technology.

The TE visits show that class A vendors invest thousands to millions of dollars on their external appearance and physical configuration by designing anchor booths and utilising different visualisation tools. Anchor booths are typically much larger than average booths and vendors use eye-caching signage, visualisation tools, giveaways and a large number of booth staff. According to Soilen [115], larger and more elaborate booths are a signalling mechanism to tell customers that this particular vendor is "the obvious choice". The observation and collected evidence at TEs show that vendors with similar strategies offered technologies that were similar at least in one character. For example, Caterpillar or Hitachi vendors had a unique design booth and exhibited new technologies such as powerful piling technology using visual and learning tools and competent interlocutors. They also had a specific conversation room, and leisure interaction opportunities. Hitachi used a specific and beautiful booth highlighting the brand as a part of the design including more than twelve booth staff, performing live music and magic lights in a specious area for conversation at a selected TE. Hyundai presented backhoes using similar strategies at the show. These vendors used more communication channels to assimilate information regarding the cutting-edge technology, whereas a mini pump is exhibited by a vendor at a standard booth using less communication and providing less information sources. Habets et al. [116] studied the adoption of innovative asphalt equipment in road construction and concluded that road construction companies with more knowledge have a preference for technologies that are more complex. Indeed, the specific characteristics of a technology could affect the vendor strategies for induction or offering the technology.

At the same time, in the same trade environment, the Ozzi Kleen exposed their technology in a Standard Box Tent type of booth with a sale person without any other attractive elements, or entertainment and communication facilities. For example, the data from TE2 shows that about $31 \%$ of vendors had small booths called standard with only one open side for serving the visitors. Likewise, less than $10 \%$ of vendors competitively had unique displays that is spacious and fully open sides in a good spot performing live demonstration or using lighting to attract visitors. 


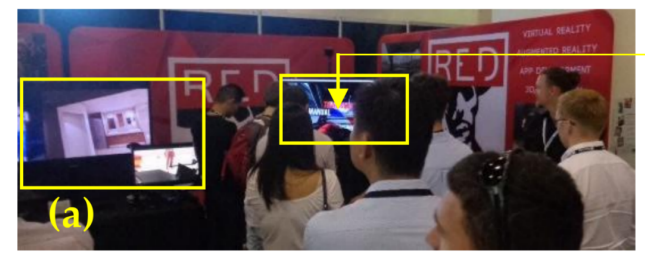

Simulator
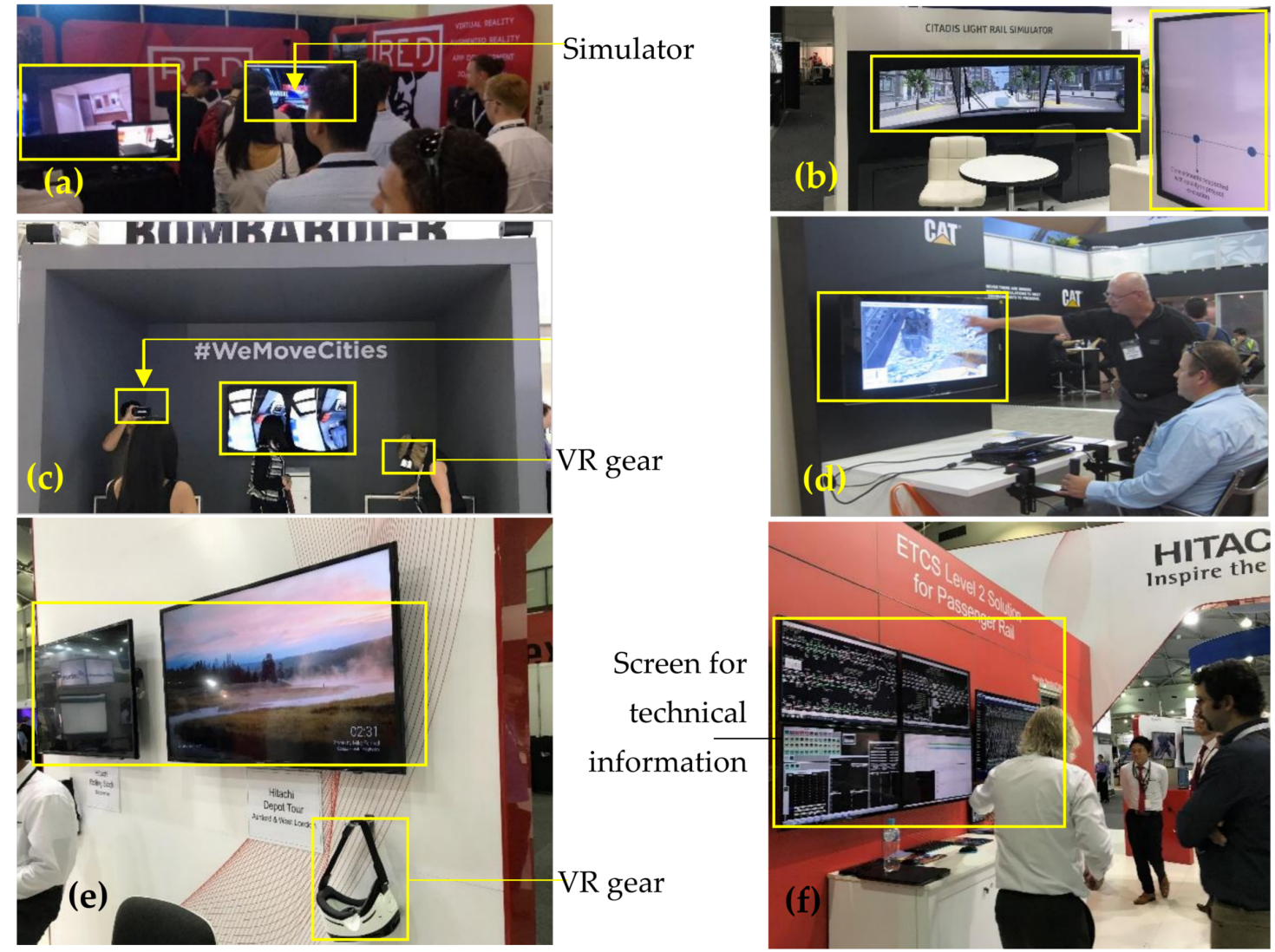

technical information

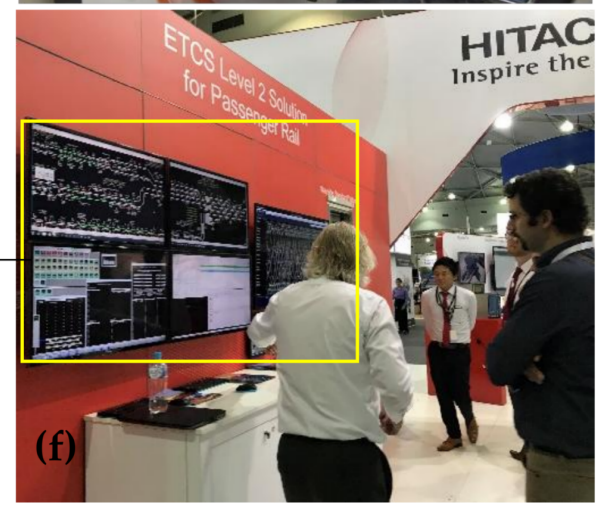

Figure 9. Virtual reality presentations are a new trend in recent TEs. (a) TE Sydney 2018; (b) light rail simulator at the rail TE in 2017; (c) A rail contractor at Brisbane Rail TE 2017; (d) training; (e) Hitachi depot tour at Ashfield and West London, at Brisbane Rail TE 2017; (f) European Train Control System demonstration at Brisbane Rail TE 2017. Note: This method of presentation grabs visitor's attention, and these booths receive more visitors than other booths. Recently, two groups of vendors offer such experience at TEs: (i) pioneers and (ii) VR suppliers.

More investigations at TEs show that the vendors implement similar strategies to offer similar technologies. For example, in front of the unique Hitachi's booth, Caterpillar established a unique design booth with live art performance and magic light (refer to Figure 10). Both also used variety of communication channels including multi-media tools to assimilate information regarding their new technologies. According to TriComB2B [76], 50\% of construction customers are mainly concerned about the safety features of the technology, while $23 \%$ customers in information technology (IT) are concerned about it. Therefore, technology application, e.g., safety, features and availability of relevant information, where the technology is complicated could affect the vendors' marketing strategies and the customers' decision.

\subsection{Interpersonal Relationship}

Customers need some information about the vendor itself and after sale services. They are willing to trust the vendor or dealer if the dealer has enough liability and responsibility or a reputation for giving reliable services. The buyer can start a relationship and acquire sufficient information at booths. According to Lee et al. [67], transfer of tacit knowledge of the equipment is very important and it can be done with a close relationship between the two sides. Such as strong relationship, so called strong tie, exhibited in buyer - vendor relationships that has positively contributed to the adoption are more likely to lead to sharing of sensitive information $[79,80]$. Thus, vendors support visitors to make a decision to move forward based on a variety of elements of booths. 
When the product is complex or has some intangible aspects, customers seek word-of-mouth information from experienced sources to better understand it [117]. Interpersonal relationships refer to any personal activities used in order to attract potential customers, follow up initial conversations toward placing an order, encourage customers to be referees and generate positive word of mouth in different events (Figure 10), and keep customers happy so that they will make future purchases.
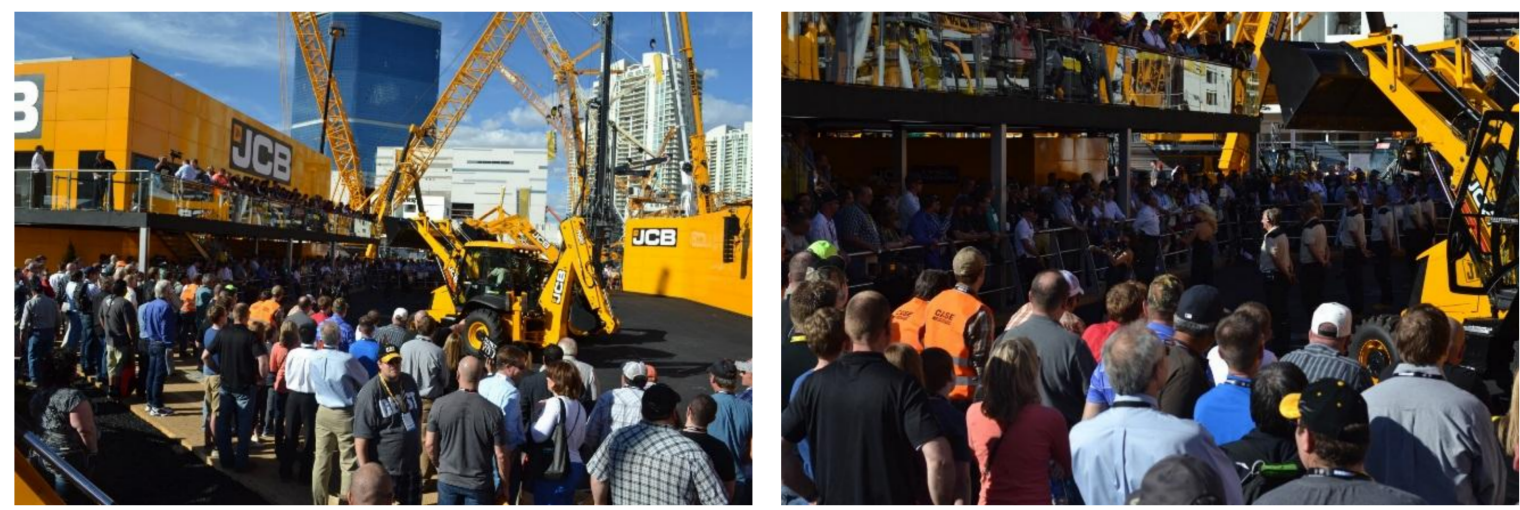

Figure 10. A vendor demonstrates their excavators in a large continental TE. Several excavators are dancing while music was playing. The dance of excavators attracted hundreds visitor's attention to this vendor and their product (CONEXPO 2014, US).

Vendors with high membership coefficients toward Cluster II (e.g., class D and class E) use their interpersonal relationship skills to draw attention to how good their product is. These products are much simpler and so customers anticipate less need for support and have greater confidence that they can appraise the technology themselves for their own use. Interpersonal relationships are important in the context of the technical exhibition because they are what draw customers to the particular products. Booths using Cluster II strategies do not have much in the way of displays that the customers can interact with on their own, so more emphasis is laid on customers interacting with the staff. Poor interpersonal interactions are a problem, because if a customer is turned off then they will not spend enough time thinking about the product to move towards purchasing it. However, good interaction will leave customers with positive feelings that will more likely lead them towards a purchase.

The type of technologies that are promoted using Cluster I (e.g., class A and class B) vendors strategies tend to be much more expensive, more critical to the success of a project, and have a greater need for customisation on site. Therefore, vendors of these technologies use their interpersonal relationship skills to convince customers that they will be there for them when needed. In particular that they will be able to customise the technology, be available for support at short notice and be able to make any necessary modifications or repairs rapidly and provide spare parts for a long time (e.g., ten years). Also, because these technologies cost a lot of money the risk associated with purchasing the wrong technology is very large and because the technologies are more complex it is more difficult for the customer to determine if the technology is the right one for them. The strategies in Cluster I exude strength and trustworthiness of the vendor. This helps to allay the anxiety and uncertainty of the customer. Providing a greater range of experts encourages the customer to trust the vendor when a particular technology is singled out as the solution to their needs.

In addition, vendors that focus on Cluster I strategies tend to provide featured space devoted to conversation (e.g., space, chairs, and tables) with customers. The provision of a spacious conversation area, food catering and social functions and entertainment encourages their current customers to attend. This attendance not only helps the vendor maintain their relationship with existing customers, but it also means that existing customers are available as referees and low-cost sources of trustworthy information to potential adopters. The entertainment aspect has been reported as a significant contributor to the perception of the exhibition effectiveness from the customer's point of view [118], and to the generation of positive word-of-mouth [117,119]. However, vendors using cluster II strategies devote their limited 
resources towards such items as written documents (e.g., exhibition papers, flyers) to communicate with customers. Therefore, they may not be able to build and follow up on such relationships at the individual level. The literature outside construction reports that relationship development is a key measure for vendor performance at an exhibition $[86,114,120]$. Therefore, vendors using Cluster II strategies will foster relationships through actions such as mass mailings.

\subsection{Technology Demonstration}

Technology demonstration refers to showing customers what the technology can do. This can be done by bringing the technology to the show and demonstrating it, bringing scale models to the show, showing videos that feature the technology in action, and/or displaying posters that explain the technology using techniques such as cut away drawings. Complexity is known as an inhibitor for successful adoption in general. Likewise, complexity is negatively associated with adoption in construction, while over time technology gradually becomes more complex and sensitive to operate. Vendors and manufacturers provide more facilities and training for more complex technologies to make them (1) easy to understand (2) easy to operate, (3) easy to maintain and repair.

Vendors with high membership coefficients toward Cluster I commonly bring large items of technology to the exhibition for display. This has the dual advantage of being eye catching and also giving customers a chance to see the technology. When possible, the vendor will set things up so that the customer can see the technology in operation. This was particularly the case in the Perth exhibition where most booths were outdoors so that large amounts of space were available for these demonstrations. It was observed that these demonstrations attract crowds of customers to look at the technology in operation. This gives these vendors a greater opportunity to start relationships with many potential customers.

Vendors with high membership coefficients toward Cluster II are more likely to have static displays rather than dynamic ones. Also, they tend to sell smaller items (light technology or tools) therefore if demonstrations are used to attract attention it is more the showmanship of the demonstrator that catches attention rather than the technology itself. Examples are shown in Table 4.

Table 4. Examples for different clusters of vendors.

\begin{tabular}{|c|c|c|c|}
\hline Vendor Cluster & Product and Examples & Technology Know-how & Knowledge Transfer \\
\hline I & $\begin{array}{c}\text { Heavy equipment (CAT, } \\
\text { Hyundai) } \\
\text { Plants (JOY, P\&H) } \\
\text { Multi product Lines } \\
\text { (Hitachi) }\end{array}$ & $\begin{array}{l}\text { Extensive activities to } \\
\text { attract potential adopters } \\
\text { (Booth type V, specific } \\
\text { conversation room) } \\
\text { Presenting technologies } \\
\text { using a wide range of } \\
\text { tools }\end{array}$ & $\begin{array}{l}\text { Generate explicit and } \\
\text { implicit knowledge } \\
\text { using about } 10 \text { personnel } \\
\text { Detail information about } \\
\text { emission, engine } \\
\text { specification }\end{array}$ \\
\hline II & $\begin{array}{l}\text { Tools } \\
\text { Mini equipment } \\
\text { Little Innovation }\end{array}$ & $\begin{array}{c}\text { Activities to attract } \\
\text { potential adopters (Booth } \\
\text { type V, specific } \\
\text { conversation room) } \\
\text { Presenting real size of } \\
\text { small scale product }\end{array}$ & \\
\hline
\end{tabular}

Vendors in both clusters will often encourage the customer to interact with the technology. For vendors of Cluster I, this might involve letting the customer sit in the cabin and operate the machine to experience its capability and flexibility. Many construction technologies now have sophisticated control systems (e.g., GPS controlled graders and dozers) that the customer may not fully comprehend the benefit of without experiencing. Similarly, tool vendors who follow Cluster II strategies will often provide a spacious booth area or large tables and cases (see the previous section) to demonstrate their technology or tools to the customers. The aim in this case is to allow the customer to pick up the tool to 
better visualise using that particular technology. Smith et al. [121] examined purchase acceleration for new products for vendors both with and without exposure at trade shows. They conclude that exposure to a trade show can "accelerate a customer's progression through the buying process." One of the aims of exposing at exhibitions is technology demonstration [63,65], and public demonstration of technology is also known to be a critical aspect of marketing [122]. The results show that most vendors put effort into demonstrating technology in static (Figure 11) and dynamic ways at TEs (Figure 12). However, different ways of exposure of the technology itself have not been paid much attention in the literature generally; this is particularly the case in the industrial trade show literature.
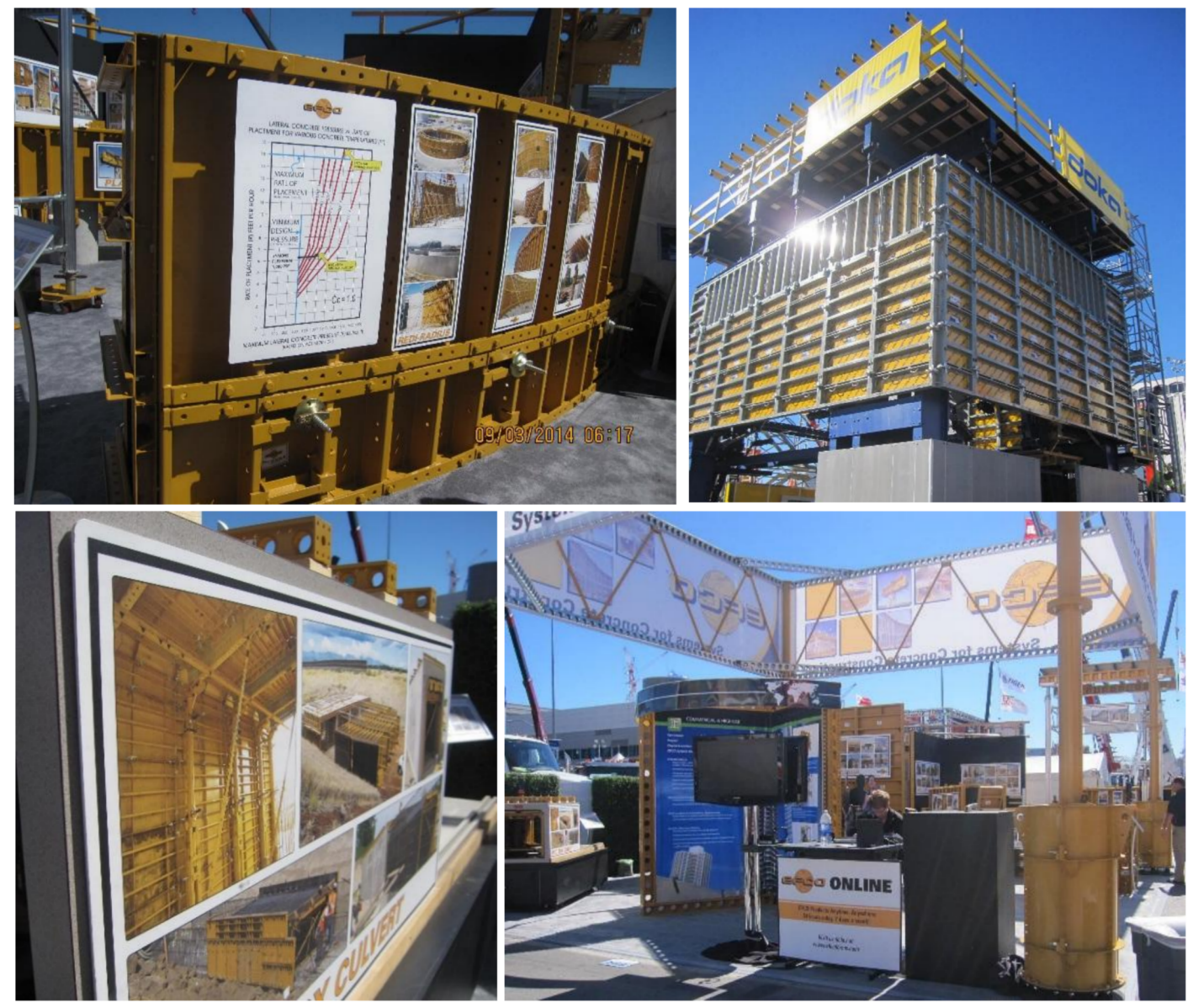

Figure 11. Demonstrating new formwork systems in different ways including written and visual information of previous projects in different contexts.

Technologies also can be grouped in order to investigate how different technologies need relevant resources to be presented in a TE. The first type of technologies consists of heavy equipment, concreting, lifting and handling equipment, earthmoving equipment and construction plant which are provided by vendors of class $A$ and class $B$.

The vendors of this group of technologies often use a wide range of different tools to attract visitors, communicate and transfer knowledge. For example, Hitachi used carefully designed island booth with LCD multimedia stands, weather proof stand frames, fabric wall displays, hanging posters, raised deck flooring and live demonstrations using sound and red lighting to focus attention on themselves. 

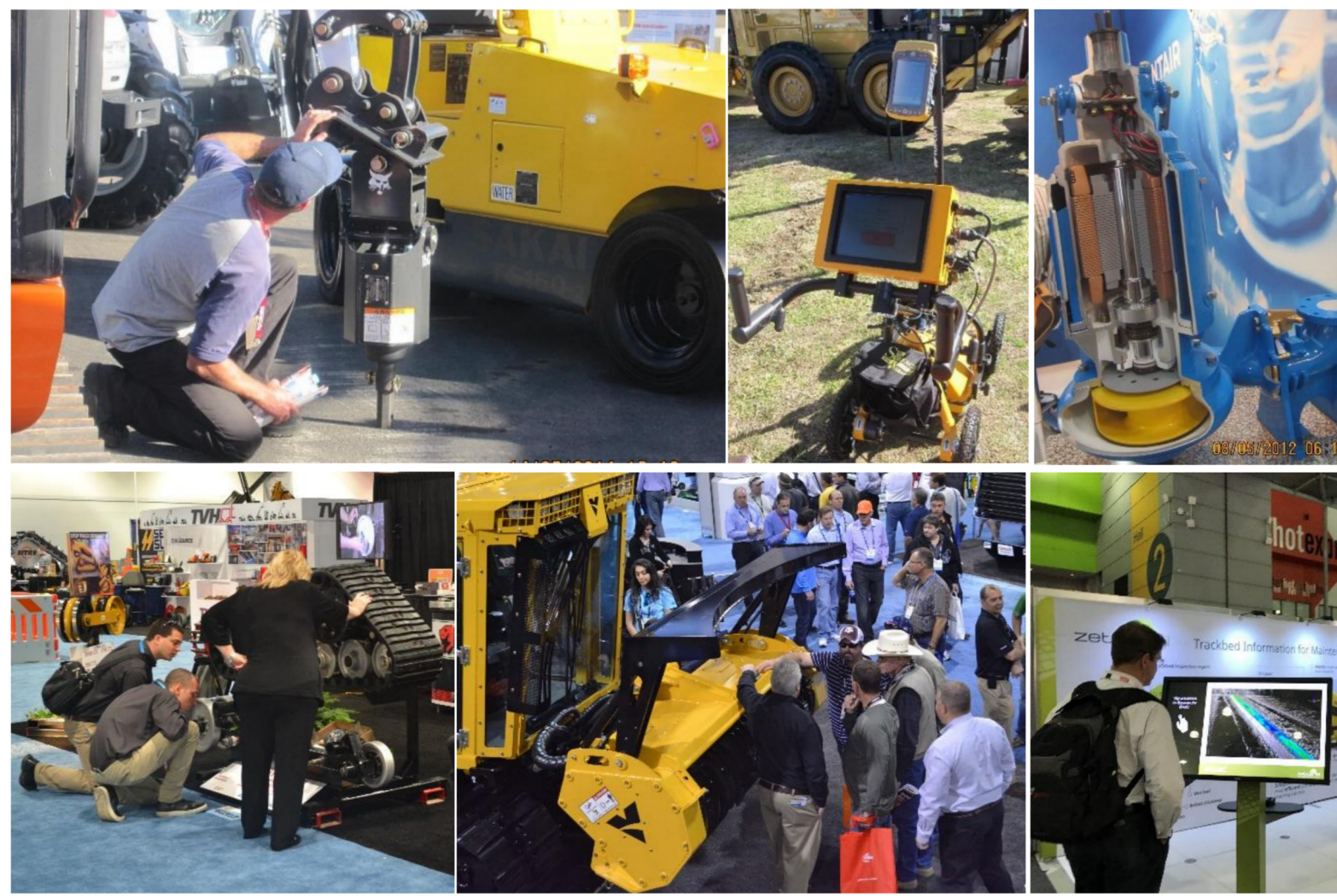

Figure 12. Customers inspecting details of new technologies to explore new mechanisms of innovative technologies.

Different types of information are shown in Table 5 Caterpillar also had live acoustic demonstrations to attract the attention of attendees. Using the k-means algorithm, it is revealed that these high-performance vendors/leaders were in tight competition and tried to dominate the TE.

Table 5. Examples of information types and tools to make it available to customers at TEs.

\begin{tabular}{ccc}
\hline Category & Type & Tools \\
\hline Paper-based information & $\begin{array}{c}\text { Catalogue, brochure, expo } \\
\text { directory book, news and } \\
\text { advertisements in newspapers }\end{array}$ & $\begin{array}{c}\text { Folding brochure stands, open shelve } \\
\text { stands, mesh brochure stands, swing } \\
\text { up brochure stands, LCD multimedia } \\
\text { stands, weather proof stand frames, } \\
\text { hanging fabric rails }\end{array}$ \\
\hline Static displays & $\begin{array}{c}\text { Teardrop flags, posters, floor } \\
\text { poster displays, billboard displays, } \\
\text { Poster displays in weatherproof } \\
\text { coverings, wall banners, } \\
\text { weatherproof light boxes } \\
\text { 3D models }\end{array}$ & $\begin{array}{c}\text { Flags, billboard frameworks, wall } \\
\text { hangings }\end{array}$ \\
\hline Digital devices & $\begin{array}{c}\text { Real samples and a section of a } \\
\text { model }\end{array}$ & Models \\
\hline $\begin{array}{c}\text { Broad casting and web-based } \\
\text { Social events and live } \\
\text { demonstration }\end{array}$ & $\begin{array}{c}\text { Video, clips, the TE electronic or } \\
\text { online directory, digital or online } \\
\text { advertisement }\end{array}$ & $\begin{array}{c}\text { TV, radio, and other electronic devices, } \\
\text { internet network }\end{array}$ \\
\hline Sales people at booths & Inside and out-side TEs & $\begin{array}{c}\text { Invitation letters, advertisements, oral } \\
\text { invitations and flyers }\end{array}$ \\
\hline & $\begin{array}{c}\text { Oral explanation, motivational } \\
\text { speakers, developing contacts to } \\
\text { provide further information }\end{array}$ & $\begin{array}{c}\text { Special space to chat, meeting room, } \\
\text { VIP, extra chairs with refreshments } \\
\text { and other attractions }\end{array}$ \\
\hline
\end{tabular}


Class A vendors were spaced in a separate and much more spacious pavilion to offer their new solutions containing cutting-edge technologies at the trades show. The world's largest makers of construction machinery such as Caterpillar, Komatsu, and Hitachi, Terex and Doosan are some of examples of technology class A. The class A vendors are reported as world's largest construction machinery markets (in order) in 2011 [123] and have unique diffusion and adoption strategies. Class $B$ vendors exhibited mostly similar types of equipment to class A vendors. Furthermore, they used less strategies to support the adoption process than the class A vendors. Figure 13 shows how a truck was demonstrated in a TE and the vendor tries to display the capability of truck to work in difficult terrains. This would appear to cause vendors of similar products to use similar sales strategies and have similar resource allocations. However, this needs to be verified.

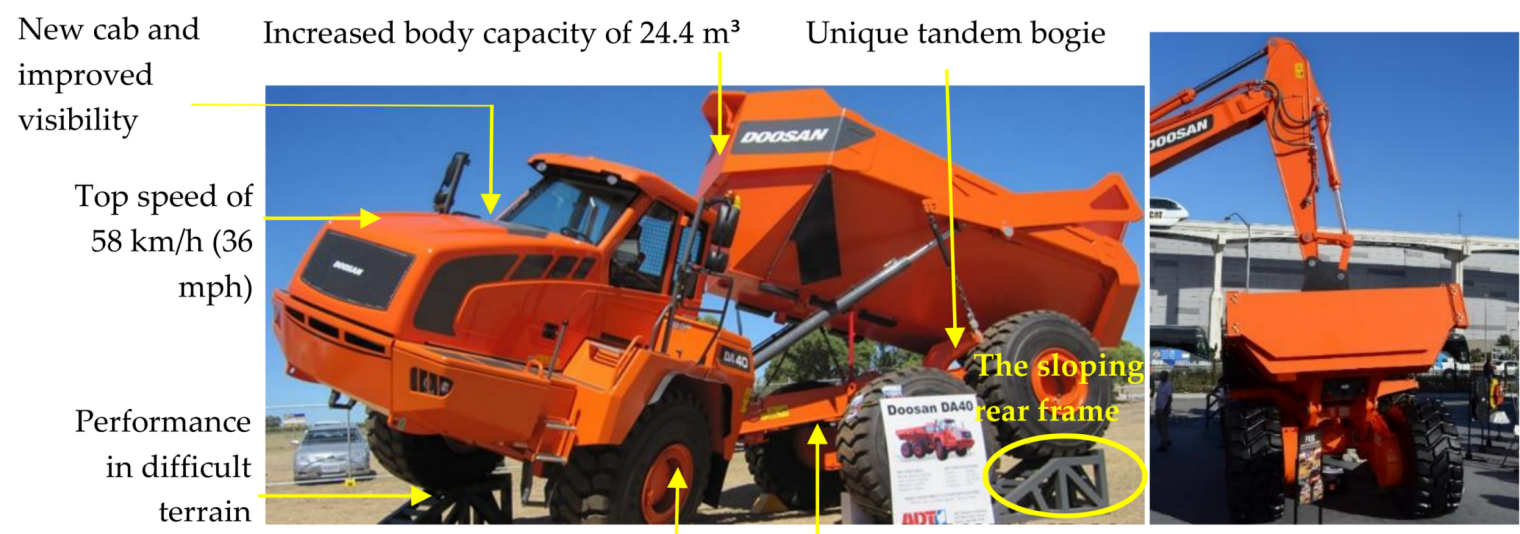

Equal power distribution on permanent 6-wheel drive The free-swinging rear tandem bogie
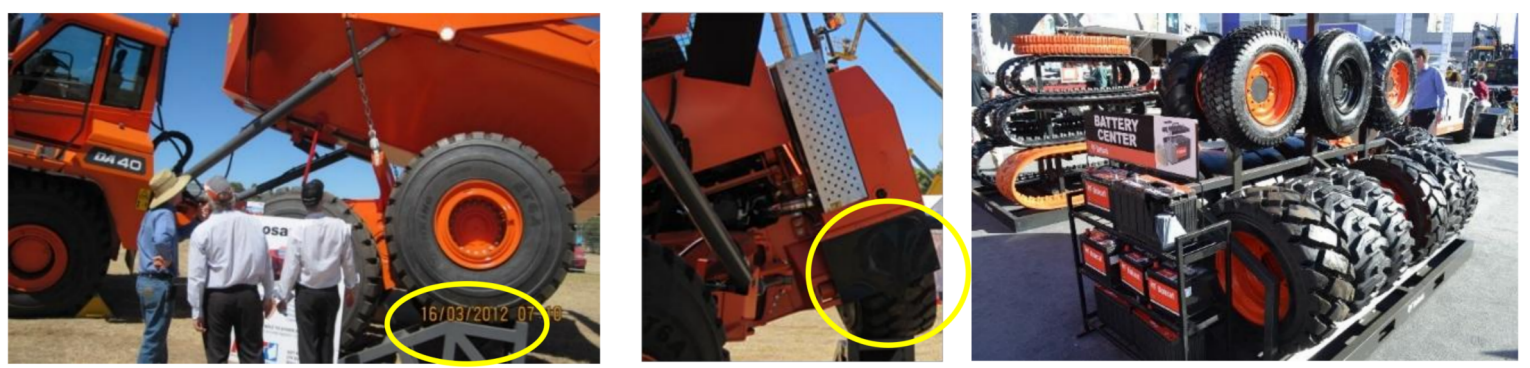

Expert Discussion
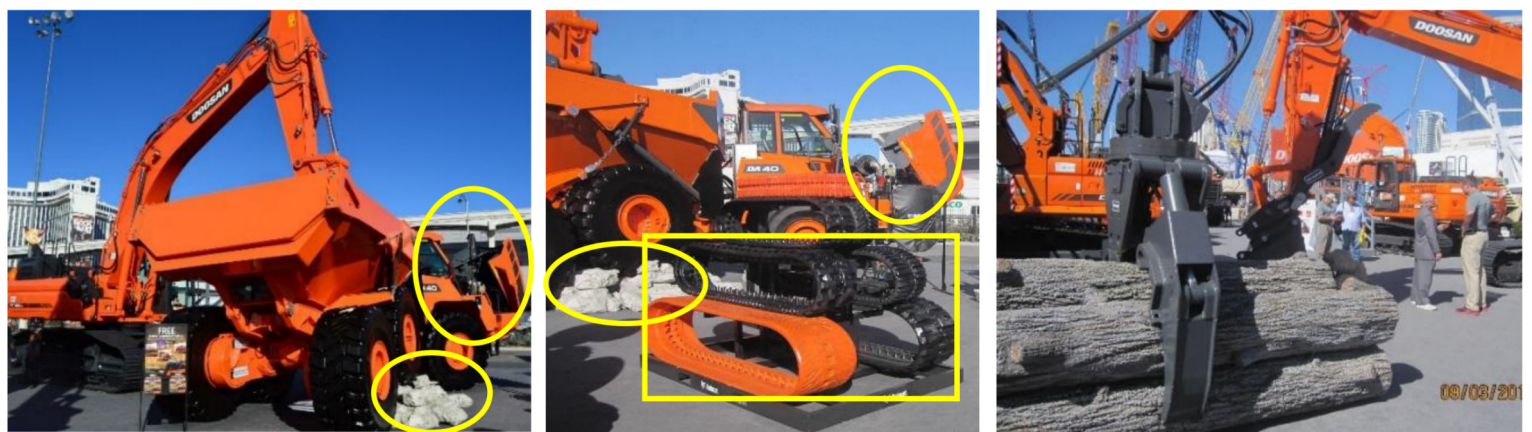

Figure 13. Different strategies to demonstrate the capability of job-site technologies at TEs. Demonstrating a truck capability to customers in a TE at Perth. Annotations in the figure are quotes from the demonstrators in the exhibitions.

This section intends to provide evidence of technology demonstration. Class A vendors use unique attractive booths overseen by professionals and staffed by welcoming marketing staff ready to discuss their technologies, of which a sample or large model might be available in the booth. Some of vendors in this class, arranged in a large part of the exhibition for live demonstration are shown in Figures 13 and 14 . 


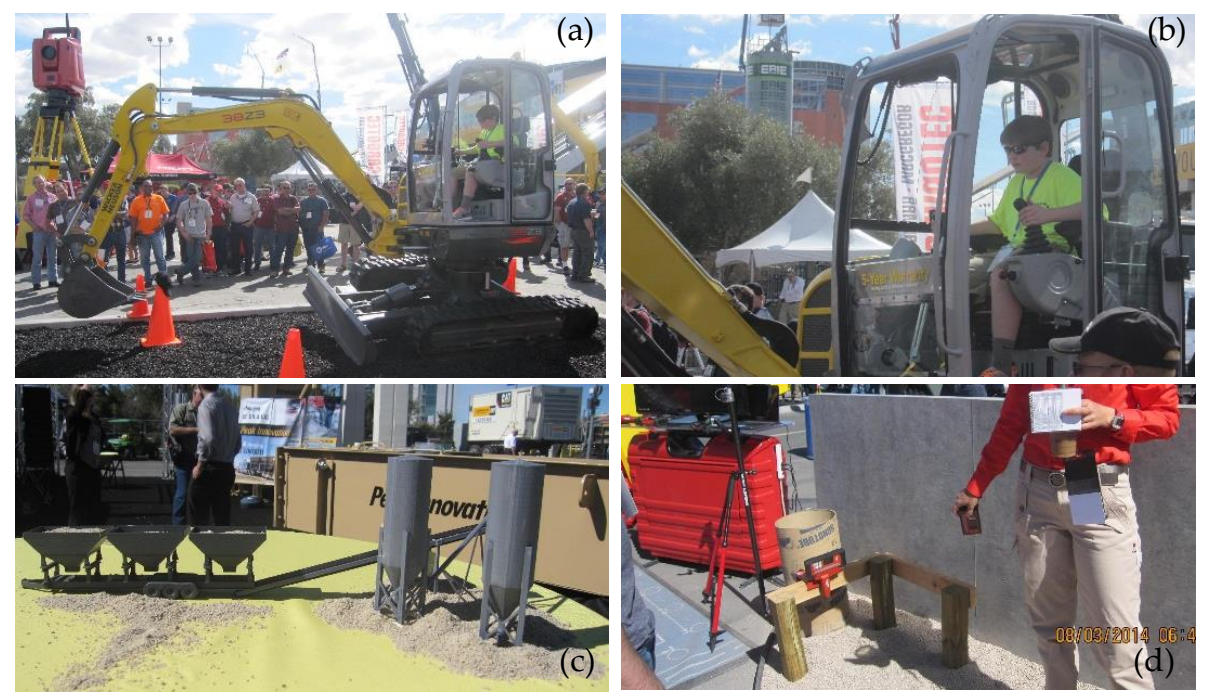

Figure 14. Live demonstrations at TEs. $(\mathbf{a}, \mathbf{b})$ demonstrating how ease of control an excavator is, by operating the excavator by a teenager at a TE. (c) demonstrating a scale model of a batching plant. (d) demonstrating a surveying tool including laser leveling for measuring distance in a TE.

Visitors have further opportunities to discuss their decision during the demonstration in a separated space in the booth, where coffee or food were provided by the vendor to encourage visitors to remain for a while to communicate. This special room is used for networking and discussion with decision makers which, outside of the event, are not available to sale persons to induce. They prefer face-to-face exposure, advanced audio-visual programmes, hands-on activities, live performances and live entertainment.

Vendors from class A mostly tend to be dominant at TEs and tried to grab visitors' attention to their brands. This could enable visitors to recall the product later with a good feeling towards the brand for inquiries and further communication. The dominance could also affect the target customers to feel confident about the potential solution and the vendor who is supposed to support the decision maker during the adoption process.

Previous studies in technology diffusion identified that Word of Mouth positively affects the technology diffusion process and facilitates the adoption process. Cluster I vendors used more than 10 personnel at the booth to attract new customers and communicate new technologies and provide required information to them. Vendors' from Cluster I technologies such as Komatsu and Hitachi provided evidence about maintenance, engine reliability, emission, easy operation, and after sales support plans. This cluster of vendors need more communication channels and efficient strategies to make the decision makers because they need to make the buyer confident about the future implementation process and after sale services. Class A vendors have more resources, and therefore, are more passionate to make relationship with the target and potential customers.

\section{Research Implications and an Agenda for Future Studies}

In this study, we found distinct strategies by which the dissemination process is initiated. This is ignored in previous studies, which they focused on modelling the technology adoption process itself $[124,125]$ or identified influential factors [126] rather than identifying the decision makers initial state and the adoption mechanism. Understanding the state is critical, because then we can modify the adoption decision and offer updated dissemination models based on relevant customers and the current practices. This study detailed the dissemination process and focused on technology demonstration by exploring three main strategies that reflect the job-site technology demonstration process. Previous studies suggested different taxonomies of potential adopters, such as innovators, early adopters, early majority, late majority, and laggards [127], pioneers and followers in in the construction industry [45], 
and visionaries and pragmatists [128] in information technologies. These taxonomies well define different characters of decision makers, but provide little guidance to vendors to disseminate new technologies, which may affect the future patterns of adoption [129].

The findings of this study provide critical information to vendors to deeply understand how competitors begin the process of demonstrating their technologies in different TEs. Using the PIT model, vendors can adapt the presentation, demonstration and communication of their technological offerings in order to achieve greater market share and faster adoption. In particular, newer vendors can learn from the empirical model because it encapsulates some of the best practices of experienced vendors in the industry.

More investigations are needed to generalise the findings of this research across different countries as well as to study the subsequent stages of the process. Similarly, we have limited our research to only one industry, and the process may be different for other industries.

The dissemination process has not received enough attention in construction $[34,45,130]$. The main research question which should be investigated further is 'what are the vendors role in the construction technology adoption process'. The present paper presented the observation and analysis of several TEs as extensive marketplace for disseminating new technologies in construction. However, TEs have not been investigated previously from these different perspectives and so there are several research questions raised during this study that should be addressed in the future.

Research issue 1: how vendors disseminate their technologies in different contexts and countries. This question is important, since the current study shows that vendors may affect the adoption process, and this may speed up the adoption process which has been of concern for decades in the construction industry.

Research issue 2: what type of vendors' dissemination strategies are most effective in the technology adoption process. The answer of this question is critical since vendors can then invest in the most effective strategy. The present paper shows that vendors utilise many different strategies and spend thousands to millions of dollars to demonstrate their technologies in different TEs around the world. However, there is not any detailed information whether any specific strategy might be very effective, and this information would enable them to disseminate their technologies with less problems and communication barriers.

Research issue 3: to what extent are green technologies and sustainable factors important to potential adopters in construction. The primarily investigation shows that these factors are less likely to have an effect on their decisions. This process should be investigated further but it requires deep understanding of the adoption process and investigating the vendors' role and strategies. Figure 15 shows vendors attempt to show their job-site technologies are green and have less footprint in environment.

Research issue 4: Visitors also can be categorised, and their typologies can be specifically identified. Customers could be divided into various categories based on different aspects such as the size of their company, nature of their organisation (e.g., family business or corporation), and/or their innovativeness (e.g., pioneers and followers) [45]. In the present paper, visitors are categorised according to their intention, need, information level and vendors marketing behaviours.

They can be also grouped based on their needs: (i) visitor/customer has an urgent need/problem for which the vendor has partial know-how and technology; (ii) the same need but there is no previous business relationship existing (no brand loyalty); (iii) the vendor has the know-how and technology because they have done business before. Many other scenarios might be existing in the market but there is no investigation and available studies to help vendors to set their marketing strategies accordingly. In response to the customer's type of agenda-relatedness browsing, vendors will take different actions. The vendors may use different strategies to attract visitors who may or may not know about the vendors. When a visitor pauses in front of the booth they intend to know whether this vendor's solution is potentially fit to their task and can solve their problem or boost the productivity, quality or speed of their construction operation. 

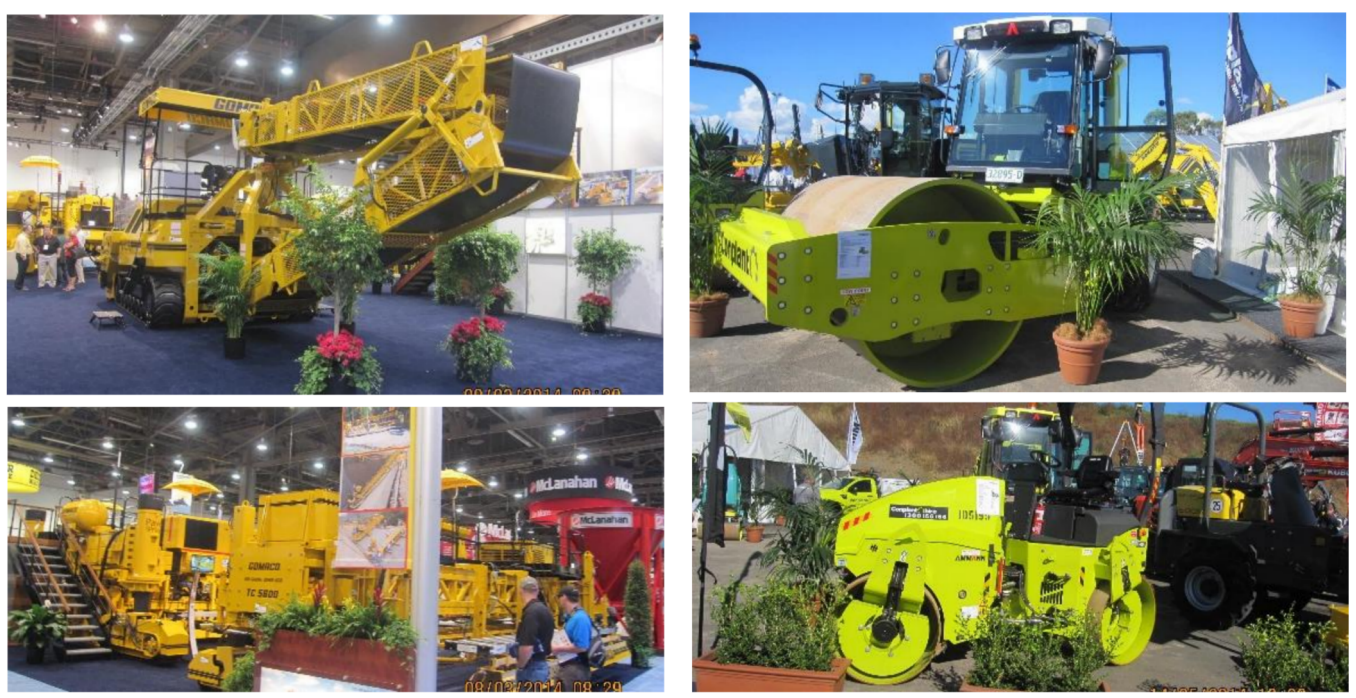

Figure 15. Demonstrating green technologies using green elements at TEs.

Research issue 5: Digital technologies can be divided into five groups: (i) office work technologies such as IT and ICT. These types of technologies are more similar software and apps which are applied and investigated in other contexts such as agriculture, banking, e-government and smart cities. (ii) design technologies such as Building Information Modelling [131-133], Geographic information Systems; (iii) job-site controlling technologies such as RFID, IoT sensors [33]; laser scanners [41-43,134-136], cameras for site management, physical progress monitoring [137] and productivity, safety and security, (iv) production technologies such as 3D Printing [138]; and (v) dependent high technologies, such as GPS, Radar and remote controlling devices and diagnostic systems attached or imbedded in heavy equipment such as Grader or Crane. The dissemination and adoption processes of the third group of technologies namely dependent digital technologies are complicated since it is a combination of a digital system and heavy equipment which will be produced by two different manufactures. The implementation challenges of these technologies should be specifically investigated further in different contexts.

\section{Conclusions}

The purpose of the present research was to extend our understanding of 'technology demonstration' strategies in the construction market. While previous studies have focused on technology dissemination and adoption processes in general, this paper investigated how a technology can be demonstrated. In addition, the paper presented the presents a new framework (PIT) describing construction technology dissemination considering three main strategic aspects: "Physical appearance", "Interpersonal relationship", and "Technology demonstration". While previous studies discussed vendors' and customers' behaviour, they have not provided in-depth information about the way a technology can be demonstrated in the construction industry.

In order to analyse the dissemination process for job site technologies in the construction market, we need to identify patterns of vendors and explore their specific and suitable strategies. Three objectives were reviewed in this paper: (i) define criteria for examining patterns of vendors' strategies to support construction companies; (ii) present evidence of different vendors' demonstration methods within different clusters; (iii) give examples of technology groups based on their required demonstration strategies. To accomplish the objectives, vendors' activities of several exhibitions were examined, and the selected booths were analysed using 38 variables with a five-point Likert scale. Then, the hierarchical clustering algorithms were used to classify vendors to explore patterns of vendors' behaviour for supporting technology adoption process. 
This study departs from previous dissemination investigations in several ways: (1) it looks at the way to assimilate information of new technologies, (2) it investigates how vendors demonstrate their products at different TEs and provides evidence for further understanding of technology demonstration based on such large empirical data, (3) it includes the cluster and thematic analysis of multiple sets of rich data to increase the robustness and generalisability of the results. This paper also presents a valuable research setting for the construction domain, because the technology adoption process is relatively slow [139], and the technology demonstration strategies may positively affect the technology adoption process.

The original contributions of the findings of this paper lie in its careful design, collection of large set of first hand data from various TEs from Australia and North America. In addition, the analysis of selected booths from vendors against the developed criteria to establish a scientifically sound understanding of the technology demonstration in the construction market is based on an innovative research method. A hierarchical cluster analysis showed that the vendors along this spectrum generally fitted into five classes. It is important to articulate the technology demonstration methods in the construction market, as it may affect the construction companies' intention to purchase and utilise a new technology in their projects. Job-site technology exhibitions are an environment in which technology is demonstrated and related information is assimilated effectively, since TEs focus on a face-to-face environment for communication between vendors and customers. Vendors are able to take advantages of opportunities at these TEs to generate awareness about their products and to impact a company's adoption decision.

The practical implication of the paper is to provide a set of marketing strategies and three key strategies to new vendors, to innovators and manufacturers, and to exhibition planners. By clearly delineating the current demonstration practices used in the industry this paper enables new vendors to see what the best strategy for them is for demonstrating their new technologies. While there will always be improvements in the strategies available for demonstrating new technologies such as virtual environments, it is important to know what the current practice is. Innovators, TE organisers and manufacturers can use knowledge of these patterns of vendor strategies and how they relate to different technologies when selecting which vendor(s) to use for introducing their new technology to the market. More specifically, industry bodies that organise TEs can use this knowledge of the vendors' strategy pattern to improve the overall ability of TEs to provide appropriate spaces and equipment to vendors to demonstrate their technologies.

Future directions and research issues were discussed in the paper, and it was suggested that the design taxonomy of physical booths and strategies are also required to communicate with customers. The PIT model also should be verified in different contexts in terms of how contact and relationships are established during preliminary discussions in order to reach the adoption decision. What is the vendors' strategy and procedure in proceeding to support a new customer and allowing them to trial a new technology in a real context? And what are the main factors influencing vendors' booth design and communication strategies?

Author Contributions: S.M.E.S. designed and conducted the research, and S.D. contributed to the interpretation of the data.

Funding: This research received no external funding.

Conflicts of Interest: The authors declare no conflict of interest.

\section{References}

1. Statista. Global Construction Machinery Market-Outlook Through 2015. Available online: http://www. statista.com/statistics/280344/size-of-the-global-construction-machinery-market/ (accessed on 26 June 2019).

2. Castro-Lacouture, D.; Medaglia, A.L.; Skibniewski, M. Supply Chain Optimization Tool for Purchasing Decisions in B2B Construction Marketplaces. Autom. Constr. 2007, 16, 569-575. [CrossRef] 
3. Miozzo, M.; Dewick, P. Building competitive advantage: Innovation and corporate governance in European construction. Res. Policy 2002, 31, 989-1008. [CrossRef]

4. Sepasgozar, M.S.; Davis, S. Construction Technology Adoption Cube: An Investigation on Process, Factors, Barriers, Drivers and Decision Makers Using NVivo and AHP Analysis. Buildings 2018, 8, 74. [CrossRef]

5. Kale, S.; Arditi, D. Innovation Diffusion Modeling in the Construction Industry. J. Constr. Eng. Manag. 2010, 136, 329-340. [CrossRef]

6. Cooper, R.G. Product Leadership: Creating and Launching Superior New Products; Perseus Books: Cambridge, UK, 1999.

7. Gourville, J.T. The Curse of Innovation: A Theory of Why Innovative New Products Fail in the Marketplace; Harvard Business School: Boston, MA, USA, 2005.

8. Heldal, I.; Fomin, V.V.; Wijkmark, C.H. Technology Adoption Failure Through the Prism of an Organizational Regulation Model. In Proceedings of the European Conference on Knowledge Management, Svalbard, Norway, 18-20 September 2018.

9. Panuwatwanich, K.; Stewart, R.A. Evaluating Innovation Diffusion Readiness among Architectural and Engineering Design Firms: Empirical Evidence from Australia. Autom. Constr. 2012, 27, 50-59. [CrossRef]

10. Li, H.; Cao, J.; Castro-Lacouture, D.; Skibniewski, M. A framework for developing a unified B2B e-trading construction marketplace. Autom. Constr. 2003, 12, 201-211. [CrossRef]

11. Ioannou, P.; Liu, L. Advanced Construction Technology System-ACTS. J. Constr. Eng. Manag. 1993, 119, 288-306. [CrossRef]

12. Allmon, E.; Haas, C.T.; Borcherding, J.D.; Goodrum, P.M. U.S. Construction Labor Productivity Trends, 1970-1998. J. Constr. Eng. Manag. 2000, 126, 97-104. [CrossRef]

13. Astebro, T. Noncapital Investment Costs and the Adoption of CAD and CNC in U.S. Metalworking Industries. RAND J. Econ. 2002, 33, 672-688. [CrossRef]

14. Hoppe, H.C. The Timing of New Technology Adoption: Theoretical Models and Empirical Evidence. Manch. Sch. 2002, 70, 56-76. [CrossRef]

15. Goodrum, P.M.; Haas, C.T. Long-Term Impact of Equipment Technology on Labor Productivity in the U.S. Construction Industry at the Activity Level. J. Constr. Eng. Manag. 2004, 130, 124-133. [CrossRef]

16. Goodrum, P.M.; Zhai, D.; Yasin, M.F. Relationship between Changes in Material Technology and Construction Productivity. J. Constr. Eng. Manag. 2009, 135, 278-287. [CrossRef]

17. Li, N.; Becerik-Gerber, B. Life-Cycle Approach for Implementing RFID Technology in Construction: Learning from Academic and Industry Use Cases. J. Constr. Eng. Manag. 2011, 137, 1089-1098. [CrossRef]

18. Zhai, D.; Goodrum, P.M.; Haas, C.T.; Caldas, C.H. Relationship between automation and integration of construction information systems and labor productivity. J. Constr. Eng. Manag. 2009, 135, 746-753. [CrossRef]

19. Schexnayder, C.J.; David, S.A. Past and Future of Construction Equipment-Part IV. J. Constr. Eng. Manag. 2002, 128, 279-286. [CrossRef]

20. Tatum, C. Process of Innovation in Construction Firm. J. Constr. Eng. Manag. 1987, 113, 648-663. [CrossRef]

21. Nicolini, D.; Holti, R.; Smalley, M. Integrating project activities: The theory and practice of managing the supply chain through clusters. Constr. Manag. Econ. 2001, 19, 37-47. [CrossRef]

22. Bowden, S.; Dorr, A.; Thorpe, T.; Anumba, C. Mobile ICT support for construction process improvement. Autom. Constr. 2006, 15, 664-676. [CrossRef]

23. Nikas, A.; Poulymenakou, A.; Kriaris, P. Investigating Antecedents and Drivers Affecting the Adoption of Collaboration Technologies in the Construction Industry. Autom. Constr. 2007, 16, 632-641. [CrossRef]

24. Harty, C. Implementing Innovation in Construction: Contexts, Relative Boundedness and Actor-Network Theory. Constr. Manag. Econ. 2008, 26, 1029-1041. [CrossRef]

25. Milliou, C.; Petrakis, E. Timing of technology adoption and product market competition. Int. J. Ind. Organ. 2011, 29, 511-523. [CrossRef]

26. IBM. Innovation Index of Australian Industry; Boreham, G., Ed.; Melbourn Institute of Appliad Economic and Social Research Melbourn: Melbourne, Australia, 2010; pp. 1-24.

27. Munkvold, B.E. Challenges of IT implementation for supporting collaboration in distributed organizations. Eur. J. Inf. Syst. 1999, 8, 260-272. [CrossRef] 
28. Sepasgozar, S.M.; Wang, C.; Shirowzhan, S. Challenges and Opportunities for Implementation of Laser Scanners in Building Construction. In Proceedings of the 33rd International Symposium on Automation and Robotics in Construction, Auburn, AL, USA, 18-21 July 2016.

29. ABS. Innovation in Australian Business in Innovation in Australian Busines; Australian Bureau of Statistics Canberra: Belconnen, Australia, 2009.

30. Sepasgozar, S.M.; Davis, S.R.; Li, H.; Luo, X. Modeling the Implementation Process for New Construction Technologies: Thematic Analysis Based on Australian and US Practices. J. Manag. Eng. 2018, 34, 05018005. [CrossRef]

31. O'Connor, J.; Yang, L. Project Performance versus Use of Technologies at Project and Phase Levels. J. Constr. Eng. Manag. 2004, 130, 322-329. [CrossRef]

32. Kang, Y.; O’Brien, W.J.; Thomas, S.; Chapman, R.E. Impact of Information Technologies on Performance: Cross Study Comparison. J. Constr. Eng. Manag. 2008, 134, 852-863. [CrossRef]

33. Shirowzhan, S.; Sepasgozarb, S.M.E.; Zainic, I.; Wangd, C. An integrated GIS and Wi-Fi based Locating system for improving construction labor communications. In Proceedings of the 34th International Symposium on Automation and Robotics in Construction, Taipei, Taiwan, 28 June-1 July 2017.

34. Sepasgozar, S.M.E.; Davis, S. Diffusion Pattern Recognition of Technology Vendors in Construction. In Construction Research Congress; American Society of Civil Engineers: Atlanta, Georgia, 2014; pp. 2106-2115. [CrossRef]

35. Sepasgozar, S.M.E.; Loosemore, M.; Davis, S.R. Conceptualising information and equipment technology adoption in construction A critical review of existing research. Eng. Constr. Archit. Manag. 2016, 23, 158-176. [CrossRef]

36. Shapira, A.; Lucko, G.; Schexnayder, C.J. Cranes for building construction projects. J. Constr. Eng. Manag. 2007, 133, 690-700. [CrossRef]

37. Seo, J.; Duque, L.; Wacker, J. Drone-enabled bridge inspection methodology and application. Autom. Constr. 2018, 94, 112-126. [CrossRef]

38. Rakha, T.; Gorodetsky, A. Review of Unmanned Aerial System (UAS) applications in the built environment: Towards automated building inspection procedures using drones. Autom. Constr. 2018, 93, 252-264. [CrossRef]

39. Shirowzhan, S.; Sepasgozar, S.M. Spatial Analysis Using Temporal Point Clouds in Advanced GIS: Methods for Ground Elevation Extraction in Slant Areas and Building Classifications. ISPRS Int. J. Geo-Inf. 2019, 8, 120. [CrossRef]

40. Shirowzhan, S.; Sepasgozar, S.M.E. Utilisation of a New Terrestrial Scanner for Reconstruction of As-built Models: A Comparative Study. In International Symposium on Automation and Robotics in Construction; Vilnius Gediminas Technical University, Department of Construction Economics \& Property: Vilnius Gediminas, Lithuania, 2015.

41. Sepasgozar, S.M.; Lim, S.; Shirowzhan, S. Implementation of Rapid As-built Building Information Modeling Using Mobile LiDAR. In Proceedings of the Construction Research Congress 2014, Atlanta, GA, USA, 19-21 May 2014; American Society of Civil Engineers: Atlanta, GA, USA, 2014. [CrossRef]

42. Shirowzhan, S.; Lim, S.; Trinder, J. Enhanced autocorrelation-based algorithms for filtering airborne lidar data over urban areas. J. Surv. Eng. 2016, 142, 04015008. [CrossRef]

43. Shirowzhan, S.; Trinder, J. Building classification from lidar data for spatio-temporal assessment of 3D urban developments. Procedia Eng. 2017, 180, 1453-1461. [CrossRef]

44. Li, H.; Chan, G.; WaiWong, J.K.; Skitmore, M. Real-time locating systems applications in construction. Autom. Constr. 2016, 63, 37-47. [CrossRef]

45. Sepasgozar, S.M.E.; Loosemore, M. The role of customers and vendors in modern construction equipment technology diffusion. Eng. Constr. Archit. Manag. 2017, 24, 1203-1221. [CrossRef]

46. Sepasgozar, S.M.E.; Li, H.; Shirowzhan, S.; Tam, V.W.Y. Methods for monitoring construction off-road vehicle emissions: A critical review for identifying deficiencies and directions. Environ. Sci. Pollut. Res. 2019, 26, 15779-15794. [CrossRef] [PubMed]

47. Hofmann-Wellenhof, B.; Lichtenegger, H.; Collins, J. Global Positioning System: Theory and Practice; Springer Science \& Business Media: Berlin, Germany, 2012.

48. Howard, J.A.; Moore, W.L. Changes in Consumer Behavior over the Product Life Cycle. Read. Manag. Innov. 1988, 2, 122-130. 
49. Rogers, E.M. Diffusion of Innovations; Free Press: New York, NY, USA, 2003.

50. Hausman, A.; Stock, J.R. Adoption and implementation of technological innovations within long-term relationships. J. Bus. Res. 2003, 56, 681-686. [CrossRef]

51. Michaelis, B.; Stegmaier, R.; Sonntag, K. The role of transformational leadership, commitment to change, and climate for initiative. J. Manag. Psychol. 2010, 25, 408-429. [CrossRef]

52. Damanpour, F.; Schneider, M. Phases of the Adoption of Innovation in Organizations: Effects of Environment, Organization and Top Managers1. Br. J. Manag. 2006, 17, 215-236. [CrossRef]

53. Ying, H.; Sepasgozar, S.M.; Akbar, N. Key Factors Affecting Construction Organizations' Acceptance of BIM: A Comparative Study. In Proceedings of the 2016 Modular and Offsite Construction [MOC] Summit, Banff, AB, Canada, 21-24 May 2019.

54. Venkatesh, V.; Thong, J.Y.L.; Chan, F.K.Y.; Hu, P.J.; Brown, S.A. Extending the two-stage information systems continuance model: Incorporating UTAUT predictors and the role of context. Inf. Syst. J. 2011, 21, 527-555. [CrossRef]

55. Oshlyansky, L.; Cairns, P.; Thimbleby, H. Validating the Unified Theory of Acceptance and Use of Technology (UTAUT) tool cross-culturally. In Proceedings of the 21st British HCI Group Annual Conference on People and Computers, Lancaster, UK, 3-7 September 2007.

56. Anderson, F.; Schaan, S. Innovation, Advanced Technologies and Practices in the Construction and Related Industries: National Estimates; Statistics Canada/National Research Council of Canada: Ottawa, ON, Canada, 2001.

57. Dubois, A.; Gadde, L.-E. The Construction Industry as a Loosely Coupled System: Implications for Productivity and Innovation. Constr. Manag. Econ. 2002, 20, 621-631. [CrossRef]

58. Gopalakrishna, S.; Lilien, G.L. A Three-Stage Model of Industrial Trade Show Performance. Mark. Sci. 1995, 14, 22-42. [CrossRef]

59. Hansen, K. Measuring Performance at Trade Shows: Scale Development and Validation. J. Bus. Res. 2004, 57, 1-13. [CrossRef]

60. Smith, T.M.; Hama, K.; Smith, P.M. The Effect of Successful Trade Show Attendance on Future Show Interest: Exploring Japanese Attendee Perspectives of Domestic and Offshore International Events. J. Bus. Ind. Mark. 2003, 18, 403-418. [CrossRef]

61. Golfetto, F.; Salle, R.; Borghini, S.; Rinallo, D. Opening the Network: Bridging the IMP Tradition and Other Research Perspectives. Ind. Mark. Manag. 2007, 36, 844-848. [CrossRef]

62. Reychav, I. Antecedents to Acquisition of Knowledge in Trade Shows. Knowl. Process Manag. 2011, 18, 230-240. [CrossRef]

63. Bettis-Outland, H.; Johnston, W.J.; Wilson, R.D. Using Trade Show Information to Enhance Company Success: An Empirical Investigation. J. Bus. Ind. Mark. 2012, 27, 384-391. [CrossRef]

64. Hakura, D.; Jaumotte, F. The Role of Inter-and Intraindustry Trade in Technology Diffusion; International Monetary Fund: Washington, DC, USA, 1999.

65. Rinallo, D.; Borghini, S.; Golfetto, F. Exploring Visitor Experiences at Trade Shows. J. Bus. Ind. Mark. 2010, 25, 249-258. [CrossRef]

66. Bettis-Outland, H.; Guillory, M.D. Emotional intelligence and organizational learning at trade shows. J. Bus. Ind. Mark. 2018, 33, 126-133. [CrossRef]

67. Lee, A.H.I.; Wang, W.-M.; Lin, T.-Y. An Evaluation Framework for Technology Transfer of New Equipment in High Technology Industry. Technol. Forecast. Soc. Chang. 2010, 77, 135-150. [CrossRef]

68. Reychav, I. Knowledge sharing in a trade show: a learning spiral model. VINE 2009, 39, 143-158. [CrossRef]

69. Kerin, R.A.; Cron, W.L. Assessing Trade Show Functions and Performance: An Exploratory Study. J. Market. 1987, 51, 87-94. [CrossRef]

70. Tanner, J.F., Jr.; Chonko, L.B. Trade show objectives, management, and staffing practices. Ind. Market. Manag. 1995, 24, 257-264. [CrossRef]

71. Holt, G.; Edwards, D. Analysis of UK Off-Highway Construction Machinery Market and Its Consumers, Using New-Sales Data. J. Constr. Eng. Manag. 2012, 139, 529-537. [CrossRef]

72. Grandzol, C.J.; Grandzol, J.R. Chantey Castings: A Hands-On Simulation to Teach Constraint Management and Demand-Driven Supply Chain Approaches. Decis. Sci. J. Innov. Educ. 2018, 16, 6-22. [CrossRef]

73. Hultsman, W. From the Eyes of an Exhibitor: Characteristics that Make Exhibitions a Success for all Stakeholders. J. Conv. Exhib. Manag. 2001, 3, 27-44. [CrossRef] 
74. Tanner, J.F., Jr. Leveling the playing field: Factors influencing trade show success for small companies. Ind. Mark. Manag. 2002, 31, 229-239. [CrossRef]

75. Situma, S.P. The Effectiveness of Trade Shows and Exhibitions as Organizational Marketing Tool (Analysis of Selected Companies in Mombasa). Int. J. Bus. Soci. Sci. 2012, 3, 219-230.

76. TriComB2B. The Considered Purchase Decision in TriComB2B 2011, TriComB2B and the University of Daytopn School of Business Adminstration Ohio. Available online: https://www.tricomb2b.com/sites/default/files/ sites/default/files/uploads/TriComB2B-UD_Research_Report-2013.pdf (accessed on 26 June 2019).

77. Geroski, P.A. Models of Technology Diffusion. Res. Policy 2000, 29, 603-625. [CrossRef]

78. Sepasgozar, S.M.; Davis, S.R.; Loosemore, M. Dissemination Practices of Construction Sites' Technology Vendors in Technology Exhibitions. J. Manag. Eng. 2018, 34, 04018038. [CrossRef]

79. Johannessen, J.-A.; Olsen, B.; Lumpkin, G.T. Innovation As Newness: What Is New, How New, and New to Whom? Eur. J. Innov. Manag. 2001, 4, 20-31. [CrossRef]

80. John, C.H.; Pouder, R.W. Technology Clusters versus Industry Clusters: Resources, Networks, and Regional Advantages. Growth Chang. 2006, 37, 141-171. [CrossRef]

81. Karahanna, E.; Straub, D.W.; Chervany, N.L. Information technology adoption across time: A cross-sectional comparison of pre-adoption and post-adoption beliefs. MIS Q. 1999, 23, 183-213. [CrossRef]

82. Harrison-Walker, L.J. The Measurement of Word-of-Mouth Communication and an Investigation of Service Quality and Customer Commitment as Potential Antecedents. J. Serv. Res. 2001, 4, 60-75. [CrossRef]

83. Sweeney, J.C.; Soutar, G.N.; Mazzarol, T. Factors influencing word of mouth effectiveness: Receiver perspectives. Eur. J. Mark. 2008, 42, 344-364. [CrossRef]

84. Godar, S.H.; O'Connor, P.J. Same Time Next Year-Buyer Trade Show Motives. Ind. Mark. Manag. 2001, 30, 77-86. [CrossRef]

85. Lee, E.-J.; Lee, J.; Schumann, D.W. The Influence of Communication Source and Mode on Consumer Adoption of Technological Innovations. J. Consum. Aff. 2002, 36, 1-27. [CrossRef]

86. Ling-yee, L. Marketing Resources and Performance of Exhibitor Firms in Trade Shows: A Contingent Resource Perspective. Ind. Mark. Manag. 2007, 36, 360-370. [CrossRef]

87. Yuksel, U.; Voola, R. Travel Trade Shows: Exploratory Study of Exhibitors' Perceptions. J. Bus. Ind. Market. 2010, 25, 293-300. [CrossRef]

88. Fichman, R.G. Information Technology Diffusion: A Review of Empirical Research. In Proceedings of the International Conference on Information Systems, Dallas, TX, USA, 13-16 December 1992; pp. $195-206$.

89. Wu, I.-L.; Chiu, M.-L. Organizational Applications of IT Innovation and Firm's Competitive Performance: A Resource-Based View and the Innovation Diffusion Approach. J. Eng. Technol. Manag. 2015, 35, $25-44$. [CrossRef]

90. Robertson, T.S.; Gatignon, H. Competitive Effects on Technology Diffusion. J. Market. 1986, 50, 1-12. [CrossRef]

91. Patton, M.Q. Qualitative Evaluation and Research Methods; Sage: Thousand Oaks, CA, USA, 1990.

92. Abowitz, D.; Toole, T. Mixed Method Research: Fundamental Issues of Design, Validity, and Reliability in Construction Research. J. Constr. Eng. Manag. 2009, 136, 108-116. [CrossRef]

93. Schultze, U.; Avital, M. Designing Interviews to Generate Rich Data for Information Systems Research. Inf. Organ. 2011, 21, 1-16. [CrossRef]

94. Denzin, N.K. The Research Act: A Theoretical Introduction to Sociological Methods; Transaction Publishers: Piscataway, NJ, USA, 1970.

95. Mathison, S. Why Triangulate? Educ. Res. 1988, 17, 13-17. [CrossRef]

96. Belk, R.W. Handbook of Qualitative Research Methods in Marketing; Edward Elgar Publishing: Cheltenham, UK, 2008.

97. Schroeder, J. Critical Visual Analysis; Belk, R, Ed.; Edward Elgar: Aldershot, UK, 2006; pp. 303-321.

98. Mitchell, A.A. The Effect of Verbal and Visual Components of Advertisements on Brand Attitudes and Attitude Toward the Advertisement. J. Consum. Res. 1986, 13, 12-24. [CrossRef]

99. Van Leeuwen, T.; Jewitt, C. The Handbook of Visual Analysis; SAGE: Thousand Oaks, CA, USA, 2001.

100. Jain, A.K. Data clustering: 50 years beyond K-means. Pattern Recognit. Lett. 2010, 31, 651-666. [CrossRef]

101. Huang, Z. Extensions to the k-Means Algorithm for Clustering Large Data Sets with Categorical Values. Data Min. Knowl. Discov. 1998, 2, 283-304. [CrossRef] 
102. Zhao, Y.; Karypis, G.; Fayyad, U. Hierarchical Clustering Algorithms for Document Datasets. Data Min. Knowl. Discov. 2005, 10, 141-168. [CrossRef]

103. Bryman, A. Social Research Methods; Oxford University Press: New York, NY, USA, 2012.

104. Corbin, J.; Strauss, A. Basics of Qualitative Research: Techniques and Procedures for Developing Grounded Theory; Sage Publications: Thousand Oaks, CA, USA, 2008.

105. Yin, R.K. Qualitative Research from Start to Finish; Guilford Press: New York, NY, USA, 2010.

106. Glaser, B.; Strauss, A. The Discovery of Grounded Theory; Weidenfield \& Nicolson: London, UK, 1967.

107. Gioia, D.A.; Corley, K.G.; Hamilton, A.L. Seeking qualitative rigor in inductive research notes on the gioia methodology. Organ. Res. Methods 2013, 16, 15-31. [CrossRef]

108. Sepasgozar, S.M.; Davis, S.; Loosemore, M.; Bernold, L. An investigation of modern building equipment technology adoption in the Australian construction industry. Eng. Constr. Archit. Manag. 2018, 25, 1075-1091. [CrossRef]

109. Corswant, F.V.; Tunälv, C. Coordinating Customers and Proactive Suppliers: A Case Study of Supplier Collaboration in Product Development. J. Eng. Technol. Manag. 2002, 19, 249-261. [CrossRef]

110. Siskind, B. Powerful Exhibit Marketing: The Complete Guide to Successful Trade Shows, Conferences, and Consumer Shows; John Wiley \& Sons: Toronto, ON, Canada, 2008.

111. Hommels, A.; Peters, P.; Bijker, W.E. Techno therapy or nurtured niches? Technology studies and the evaluation of radical innovations. Res. Policy 2007, 36, 1088-1099. [CrossRef]

112. Felin, T.; Zenger, T.R. Closed or Open Innovation? Problem Solving and the Governance Choice. Res. Policy 2014, 43, 914-925. [CrossRef]

113. Gopalakrishna, S.; Roster, C.A.; Sridhar, S. An exploratory study of attendee activities at a business trade show. J. Bus. Ind. Market. 2010, 25, 241-248. [CrossRef]

114. Lee, C.H.; Kim, S.Y. Differential Effects of Determinants on Multi-dimensions of Trade Show Performance: By Three Stages of Pre-show, At-show, and Post-show Activities. Ind. Market. Manag. 2008, 37, 784-796. [CrossRef]

115. Soilen, K.S. Trade Show Intelligence. In Exhibit Marketing and Trade Show Intelligence; Springer: New York, NY, USA, 2013; pp. 127-136.

116. Habets, T.; Voordijk, H.; van der Sijde, P. The adoption of innovative asphalt equipment in road construction. Constr. Innov. Inf. Process Manag. 2011, 11, 229-245. [CrossRef]

117. Bansal, H.S.; Voyer, P.A. Word-of-mouth Processes within a Services Purchase Decision Context. J. Serv. Res. 2000, 3, 166-177. [CrossRef]

118. Gottlieb, U.; Brown, M.; Ferrier, L. Consumer Perceptions of Trade Show Effectiveness: Scale Development and Validation within a B2C Context. Eur. J. Market. 2014, 48, 89-107. [CrossRef]

119. Buttle, F.A. Word of mouth: Understanding and Managing Referral Marketing. J. Strateg. Market. 1998, 6, 241-254. [CrossRef]

120. Kreivi, M. Matti Muhos, Lingyun Wang, and Pekka Kess. Trade Fairs to Advance SME Internationalisation: Case China, Industrial Engineering and Management Working Papers 2011/6. 2011. Available online: https: //pdfs.semanticscholar.org/eda9/3cc4be8353020e03d51940b65712572deefe.pdf (accessed on 29 June 2019).

121. Smith, T.M.; Gopalakrishna, S.; Smith, P.M. The complementary effect of trade shows on personal selling. Int. J. Res. Market. 2004, 21, 61-76. [CrossRef]

122. Aspers, P.; Darr, A. Trade Shows and the Creation of Market and Industry. Sociol. Rev. 2011, 59, 758-778. [CrossRef]

123. KHLGrouThe world's Largest Construction Machinery Manufacturers in 2011.2012 cited 2013. Available online: http://www.statista.com/statistics/234198/leading-construction-machinery-manufacturersworldwide-based-on-revenue/ (accessed on 29 June 2019).

124. Didehvar, N.; Teymourifard, M.; Mojtahedi, M.; Sepasgozar, I.D. An Investigation on Virtual Information Modeling Acceptance Based on Project Management Knowledge Areas. Buildings 2018, 8, 80. [CrossRef]

125. Foroozanfar, M.; Samad, M.E.S. Modeling Green Digital Technology Implementation in Construction. In Proceedings of the Construction Research Congress, New Orleans, LA, USA, 2-4 April 2018.

126. Peansupap, V.; Walker, D. Exploratory Factors Influencing Information and Communication Technology Diffusion and Adoption within Australian Construction Organizations: A Micro Analysis. In Construction Innovation; Sage: Thousand Oaks, CA, USA, 2005; pp. 135-157.

127. Rogers, E.M. Diffusion of Innovations, 4th ed.; Free Press: New York, NY, USA, 1995. 
128. Moore, G.A. Crossing the Chasm: Marketing and Selling High-Tech Products to Mainstream Consumers; HarperBusiness: New York, NY, USA, 1991.

129. Tidd, J. A Review of Innovation Models; Imperial College London: London, UK, 2006.

130. Sepasgozar, S.M.; Davis, S.R. A Decision Framework for Advanced Construction Technology Adoption. In Proceedings of the Transportation Research Board 94th Annual Meeting, Washington, DC, USA, 11-15 January 2015.

131. Hong, Y.; Hammad, A.W.A.; Sepasgozar, S.; Akbarnezhad, A. BIM adoption model for small and medium construction organisations in Australia. Eng. Constr. Archit. Manag. 2018, 26, 154-183. [CrossRef]

132. Hong, Y.; Samad, M.E.; Sepasgozar, A.; Ahmadian, F.F.; Akbarnezhad, A. Factors influencing BIM adoption in small and medium sized construction organizations. In Proceedings of the 33rd ISARC, Auburn, AL, USA, 18-21 July 2016.

133. Shirowzhan, S.; Sepasgozar, S.M.E.; Li, H.; Trinder, J. Spatial compactness metrics and Constrained Voxel Automata development for analyzing 3D densification and applying to point clouds: A synthetic review. Autom. Constr. 2018, 96, 236-249. [CrossRef]

134. Sepasgozar, S.M.E.; Limb, S.; Shirowzhanc, S.; Kimd, Y.M. Implementation of As-Built Information Modelling Using Mobile and Terrestrial Lidar Systems. In Proceedings of the 31st International Symposium on Automation and Robotics in Construction and Mining, Sydney, Australia, 9-11 July 2014.

135. Sepasgozar, S.M.E.; Forsythe, P.; Shirowzhan, S. Evaluation of terrestrial and mobile scanner technologies for part-built information modeling. J. Constr. Eng. Manag. 2018, 144, 04018110. [CrossRef]

136. Shirowzhan, S.; Sepasgozar, S.M.E.; Li, H.; Trinder, J.; Tang, P. Comparative analysis of machine learning and point-based algorithms for detecting 3D changes in buildings over time using bi-temporal lidar data. Autom. Constr. 2019, 105, 102841. [CrossRef]

137. Shirowzhan, S.; Sepasgozar, S.; Liu, C. Monitoring physical progress of indoor buildings using mobile and terrestrial point clouds. In Proceedings of the Construction Research Congress, New Orleans, LA, USA, 2-4 April 2018.

138. Tahmasebinia, F.; Niemelä, M.; Sepasgozar, S.M.E.; Lai, T.Y.; Su, W.; Reddy, K.R.; Shirowzhan, S.; Marroquin, F.A. Three-Dimensional Printing Using Recycled High-Density Polyethylene: Technological Challenges and Future Directions for Construction. Buildings 2018, 8, 165. [CrossRef]

139. Sepasgozar, S.M.; Bernold, L.E. Factors Influencing the Decision of Technology Adoption in Construction. In Proceedings of the Developing the Frontier of Sustainable Design, Engineering, and Construction-ICSDEC, Fort Worth, TX, USA, 7-9 November 2012. 